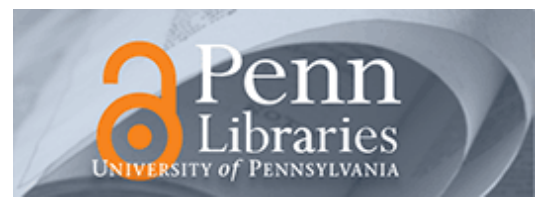

University of Pennsylvania

ScholarlyCommons

Management Papers

Wharton Faculty Research

$7-2013$

\title{
What Happened to Long-Term Employment? The Role of Worker Power and Environmental Turbulence in Explaining Declines in Worker Tenure
}

Matthew J. Bidwell

University of Pennsylvania

Follow this and additional works at: https://repository.upenn.edu/mgmt_papers

Part of the Business Administration, Management, and Operations Commons, Performance Management Commons, and the Training and Development Commons

\section{Recommended Citation}

Bidwell, M. J. (2013). What Happened to Long-Term Employment? The Role of Worker Power and Environmental Turbulence in Explaining Declines in Worker Tenure. Organization Science, 24 (4), 1061-1082. http://dx.doi.org/10.1287/ orsc.1120.0816

This paper is posted at ScholarlyCommons. https://repository.upenn.edu/mgmt_papers/124

For more information, please contact repository@pobox.upenn.edu. 


\title{
What Happened to Long-Term Employment? The Role of Worker Power and Environmental Turbulence in Explaining Declines in Worker Tenure
}

\begin{abstract}
Recent declines in the average length of time that U.S. workers spend with a given employer represent an important change in the nature of the employment relationship, yet it is one whose causes are poorly understood. I explore those causes using Current Population Survey data on the tenure of men aged 30-65, from the years 1979-2008.

I argue that long-term employment relationships primarily occur when workers pressure employers to close off employment from market competition, reducing the attractiveness of external mobility relative to internal opportunities and increasing employment security. I then explore how two changes in organizations' environments-a decline in union strength and increased turbulence from changes in technology and globalization-might have affected workers' ability to secure such closed employment relationships over the last 30 years.

My results support the argument that declines in tenure reflect the reduced power of workers to secure closed employment relationships. Recent declines in tenure have been concentrated in large organizations, and many of those declines are explained by controlling for the changing levels of industry unionization. I find little evidence that foreign competition or technological change affected mobility. The results are robust to measures of changing industry growth rates and within-industry reorganization.

Supplementary analyses suggest that layoffs are associated with different industry pressures than tenure and that voluntary mobility may have played an important role in declines in tenure.
\end{abstract}

\section{Keywords}

tenure, unions, employment relationships, worker mobility, boundaryless careers, layoffs, internal labor markets, organizational size, technological change, international competition

\section{Disciplines}

Business Administration, Management, and Operations | Performance Management | Training and Development 
WHAT HAPPENED TO LONG TERM EMPLOYMENT? THE ROLE OF WORKER POWER AND ENVIRONMENTAL TURBULENCE IN EXPLAINING DECLINES IN WORKER TENURE

\author{
Matthew Bidwell \\ The Wharton School \\ mbidwell@wharton.upenn.edu
}

Forthcoming, Organization Science 


\begin{abstract}
Recent declines in the average length of time that US workers spend with a given employer represent an important change in the nature of the employment relationship, yet one whose causes are poorly understood. I explore those causes using Current Population Survey data on the tenure of men aged 30-65.
\end{abstract}

I argue that long term employment relationships primarily occur when workers pressure employers to close off employment from market competition, reducing the attractiveness of external mobility relative to internal opportunities, and increasing employment security. I then explore how two changes in organizations' environments might have affected workers' ability to secure such closed employment relationships: a decline in union strength, and increased turbulence from changes in technology and globalization.

My results support the argument that declines in tenure reflect the reduced power of workers to secure closed employment relationships. Recent declines in tenure have been concentrated in large organizations, and much of those declines are explained by controlling for the changing levels of industry unionization. I find little evidence that foreign competition or technological change affected mobility. The results are robust to measures of changing industry growth rates and within-industry reorganization. Supplementary analyses suggest that layoffs are associated with different industry pressures than tenure, and that voluntary mobility may have played an important role in declines in tenure. 
The last thirty years have seen a persistent decline in the average duration of employment relationships within the US, with experienced men, who were previously most likely to be in long term employment, most affected (Farber 2008a; Hollister 2011). Those changes in tenure have manifested as particularly marked declines in the proportion of workers who have been with their employer for more than ten years, and strong increases in the proportion who have moved jobs within the last year (Farber 2008a). Many commentators argue that these changes represent a fundamental shift in the nature of careers and the employment relationship (Arthur and Rousseau 1996; Cappelli 1999; Osterman 1999).

Certainly, long term employment was a fundamental assumption underpinning much of the behavior of workers and managers, and declines in tenure therefore have the potential to affect a wide range of outcomes. For example, long term employment has been associated with psychological and social contracts based around trust and loyalty (Osterman et al. 2001; Rousseau 1995), and research has associated short term employment with declines in such loyalty (Tsui et al. 1997). Long term employment also encouraged firms to invest in training and workers to invest in firm specific skills; the decline in tenure has prompted both parties to pull back from such investments (Cappelli 1999, 2008). Ethnographic work also highlights the role of long term employment in providing stability in workers' lives and an opportunity for the construction of a coherent identity (Bauman 1998; Sennett 1998). The loss of that stability has made the construction of such a coherent narrative far harder (Sennett 1998).

Declines in tenure also imply that workers are increasingly moving between jobs using external labor markets: as workers spend less time with a single employer, so they must be moving between firms more frequently. It is possible that such a change is helping workers to find the jobs that best suit their skills and needs (Jovanovic 1979). More concretely, mobility through external labor markets affects workers' access to pay and opportunity: in high skilled populations, workers who move across firms appear to achieve faster pay growth (Brett and Stroh 1997); among younger workers, however, there is evidence that declining tenure has slowed wage growth (Bernhardt et al. 2001), and increased mobility has also affected racial earnings disparities (Kronberg 2010); external hiring also leads different kinds of workers to be placed into jobs than does internal mobility (Baker et al. 1994; Bidwell 2011; Petersen and 
Saporta 2004), advantaging those with more visible credentials while also providing more opportunities for discrimination.

Such profound consequences of changing worker tenure and mobility beg an explanation for why the duration of employment relationships has fallen; if we want to understand how worker tenure is likely to evolve in the future, or even the kinds of measures by workers, employers or government that might affect the development of employment relationships, we need to understand the causes of changes in the past. Yet there has seen surprisingly little systematic analysis of the reasons that tenure has declined. Much effort has gone into documenting the existence of declines in worker tenure and understanding the demographic groups that have been most effected (Bernhardt et al. 2001; Farber 2008a; Hollister 2011; Neumark et al. 1999). Some scholars have also studied the related phenomenon of downsizing (Baumol et al. 2003; Budros 1999; Fligstein and Shin 2007), demonstrating a role for poor profitability and declining share prices in firms' decisions to downsize. While this literature provides valuable insights into important changes in the employment relationship, it is not clear that declines in tenure reflect an increase in downsizing: much data suggests that workers have become, if anything, less likely to suffer involuntary termination since 1980 (prior, at least, to the great recession of 2008) (Davis 2008; Davis et al. 2008; Farber 2008b). Other scholars have offered anecdotal accounts of the reasons for declining worker-firm attachment, based on technological change, global competition, and shareholder pressures (Cappelli 1999; Osterman 1999; Pfeffer and Baron 1988). However, there has been little attempt to systematically test those different explanations for declining worker-firm attachment. Hence, while we know that tenure has declined, and we have some possible explanations, we lack detailed analysis that could support or challenge any of those accounts.

In part, the lack of evidence on the causes of declining worker tenure may reflect the difficulties of exploring this question. It is likely that declines in worker tenure reflect changes in the way that the employment relationship is structured within organizations, but we lack longitudinal data that details how those relationships have changed over the last 30 years. In this paper, I seek to make some progress towards understanding declines in worker tenure by drawing on 30 years of data from the Current 
Population Survey (CPS). The CPS is a government survey that has irregularly asked workers about their tenure with their current employer, providing consistent, economy-wide measures of worker tenure from the end of the 1970s to the present. Although labor economists have used this data to document declines in worker tenure (Farber 2008a; Neumark et al. 1999), they have not exploited information on the nature of employing organizations to explore the causes of that decline. While the survey contains little information on the specifics of organizational practices, the identity of the employer, the nature of workers' prior jobs or why they left them, I am able to match the data to information on current employer size and industry characteristics. I show how using these basic organizational characteristics allows us to test different arguments about the causes of declining tenure.

I develop a simple theoretical framework to understand those changes in tenure. I argue that long term employment relationships primarily occur when workers persuade employers to "close off” employment, protecting workers from market competition (Sorensen 2000; Weber 1968). Such closed relationships provide current employees with higher rewards and better opportunities inside the organization, making it less attractive for them to leave. They also improve workers' job security. Yet such closure may often be costly to employers, reducing flexibility and helping workers to maintain higher wages. Whether the organization fosters long term employment relationships therefore depends on workers’ ability to secure such closed employment relationships from employers.

I then explore how two sets of changes in organizations’ environments could have affected workers’ ability to secure closed employment relationships: declining union strength which reduced workers' bargaining power; and increased foreign competition and technological changes which increased the costs to employers of long-term employment relationships. I also argue that each of these changes was most likely to have affected large organizations.

I exploit variation in the way that these broad economic changes have affected different industries to test these arguments. I focus my analyses on a particular subsection of the population: men aged 30-65. It was this group that was most likely to have stable, long term employment relationships during the postwar period, and should therefore have seen the greatest changes. Focusing on men also avoids the 
confounding effects on tenure caused by the increasing tendency of married mothers to stay in their jobs (Hollister and Smith 2011). My results show that declines in tenure have been concentrated in large organizations, and that much of this change can be explained by controlling for the changing levels of unionization across industries. While other work documents a relationship between unions and worker tenure (e.g. Pfeffer 1983), I provide the first evidence of a strong association between the decline of unions and the decline of long-term employment. These results demonstrate the important role that societal power has played in shaping changes to the employment relationship and workers' careers.

\section{THEORY: TENURE, WORKER POWER AND EMPLOYER COSTS}

In this paper, I examine the reasons for changes in worker tenure, defined as the length of time that workers have spent with their current employer. Ultimately, the average level of tenure in an organization reflects when the workforce was hired. Sometimes, that hiring occurs when the organization grows; at other times, hiring is used to replace existing workers following turnover (although such replacement hiring may be more likely to occur following voluntary turnover, even layoffs are often followed by hiring into other areas (Baumol et al. 2003)). Tenure distributions also reflect who leaves the organization: holding exit rates constant, a loss of more senior workers will reduce average tenure. As a consequence, tenure may decline during downsizing if organizations target long-serviced workers.

Some studies have examined how organizational growth might have affected average levels of tenure. For example, Diprete (1993) and Shin (2007) show how industrial restructuring leads workers to move from declining industries to growing ones, and argue that such processes may have contributed to declines in tenure in the 1980s and 1990s. Many other accounts, however, argue that the same period also saw substantial changes in the nature of the worker-employer relationship that might have affeted voluntary and involuntary turnover (Osterman 1999; Pfeffer and Baron 1988). I focus on testing this latter set of accounts, although I also explore the effects of reallocating workers across industries.

\section{Long Term Employment Relationships and Closure}

A central argument of this paper is that long term employment relationships were a consequence of closed employment relationships, which insulated workers from the external labor market. Although 
scholars have explored many individual-level determinants of turnover (Griffeth et al. 2000; Hom and Kinicki 2001), research has also emphasized the organizational roots of turnover. Workers leave their jobs when they believe that a job in another organization will provide greater rewards than their current position (Griffeth et al. 2000; March and Simon 1958). How employers reward different jobs and regulate opportunities therefore affects worker tenure.

Sociological theories of closure (Murphy 1988; Weber 1968) offer a useful lens for understanding how organizations regulate employment. Employment relationships can be described as “open”, offering opportunities to all qualified workers, or "closed”, restricting access to a limited group of eligible workers (Sorensen and Kalleberg 1981; Weeden 2002). ${ }^{1}$ During the post-war period, employment relationships often became closed off through a series of practices that favored existing employees in the allocation of opportunities. For example, firms often preferred to use internal promotions to fill higher level positions, with some scholars even arguing that firms restricted external hiring to a few "ports of entry” (Althauser and Kalleberg 1981; Pfeffer and Cohen 1984). Internal job posting systems gave further advantages to internal candidates by making them more aware of opportunities. The frequent use of seniority to allocate promotions, set pay and benefits and decide layoffs further benefited workers who stayed at the organization longer (Jacoby 1985; Kerr 1977; Slichter et al. 1960). Contemporary scholars argued that these practices resulted in a Balkanization of the labor market, as competition for higher level jobs in an organization became closed off to all but those few workers already working in the organization (Kerr 1977).

Those closed employment relationships promoted long term employment because of their effects on both voluntary and involuntary turnover. Once a worker had accrued seniority within a closed employment relationship they had better rewards, access to higher level jobs and employment security than would be available on the external labor market. Moving meant a loss of those advantages, making

\footnotetext{
${ }^{1}$ My definition of closed employment differs slightly from that of Sorensen and Kalleberg (1981). They defined closed employment solely in terms of the ability of workers to be displaced from their existing job by outsiders. My definition also encompasses the preferential availability to existing employees of other jobs within the same organization, consistent with the broader use of closure in the literature (Murphy 1988; Weber 1968).
} 
workers in closed employment relationships less likely to move voluntarily, particularly once they had gained higher tenure (Kerr 1977:31-32; Slichter et al. 1960:139). Jacoby accordingly noted that "the drop in mobility was one of the most important consequences of the system that had become widespread for manufacturing workers [during the postwar period]. Seniority rules and internal promotion policies gave workers a reason to remain with their employers” (1985:206). Closed employment relationships may also have reduced involuntary mobility, by making it more difficult for firms to discharge workers, other than as part of layoffs. Even when layoffs occurred, the use of seniority in allocating security meant that those layoffs fell largely on the less tenured, increasing average tenure.

\section{Closure and Conflict}

Theories of closure argue that closed relationships are an object of conflict, because of the way that they reduce competition to the detriment of customers (Murphy 1988). As a consequence, actors must often exercise power to create and maintain closure (Murphy 1988:9). Such dynamics are evident in the employment context. Because closing off employment reduced competition for many jobs, it gave existing employees enhanced access to opportunities for upwards mobility. That reduced competition could also help workers to secure the returns to their efforts (Sorensen 2000; Weber 1968:341-342), counterbalancing the advantages that employers otherwise enjoyed. For employers, the benefits of closure were at best ambiguous. Lower turnover could benefit employers by promoting investments in firm specific skills. At the same time, the advantages given to workers constrained managerial prerogatives in allocating jobs and rewards, reduced their flexibility in responding to changes in demand or skills needs, and limited their ability to use external competition to hold down wages.

Because of these conflicting interests, much evidence suggests that workers were only able to acquire closed employment practices through the exercise of power. In general, workers can draw on two sources of power in seeking to influence employers' behavior. First, the threat of individual exit requires employers to offer terms that are at least as good as workers could receive elsewhere. Second, the use of collective bargaining allows workers to threaten employers with strikes and other collective action. This second, collective source of power appears to have played a particularly important role in shaping the 
adoption of the internal labor market practices that fostered closure. Several explanations have been advanced for firms' adoption of internal labor market practices, with some scholars arguing that they reflected firms’ desire to drive down turnover and foster investment in firm specific skills (Cappelli 2000; Doeringer and Piore 1971), and others noting the role of government intervention (Baron et al. 1986). Much research, though, points to the role of collective worker pressure. For example, Baron et al (1986) find that the diffusion of seniority related practices was strongly related to unionization, and Slichter et al (1960:140-141) describe how unions promoted seniority provisions over the objections of management. Other studies describe how the adoption of closed practices by non-union firms was also a response to worker pressure, as employers used those closed relationships to pre-empt unionization and secure labor peace (Jacoby 1985). ${ }^{2}$ Work in the dual labor market literature also emphasized worker power as a key resource for achieving closed employment relationships (Hodson and Kaufman 1982), while Pfeffer (1983) described unionization as a principal determinant of long term employment relationships.

\section{What Changed?}

If long-term employment relationships originally reflected workers’ power to secure closed employment relationships, then the recent decline in long-term employment may reflect a reduction in their ability to secure such closure. Given that the decline in long-term employment has happened across large numbers of different organizations, such a shift in the nature of worker-employer bargaining is most likely to be the result of broad economic or social changes. Below, I explore two sets of changes that might have made it more difficult for workers to secure closure: declining union strength that weakened worker power; and increased foreign competition and technological change that made long term employment more costly for employers.

Deunionization and changes in tenure. I have noted that the ability of workers' to secure closed employment relationships was firmly rooted in their ability to organize collectively through unions. The last thirty years have seen a collapse in private sector union membership, partly as a consequence of

\footnotetext{
${ }^{2}$ Radical critiques of internal labor markets offer a contrary perspective, viewing such practices as a means for managers to exert control over workers (Edwards 1979). It is difficult to find strong empirical support for those arguments in studies of internal labor market adoption, though.
} 
declining legal and normative support for unions. These changes have reduced workers' ability to exert collective power and might account for declines in tenure.

Scholars have debated the reasons behind union decline (Freeman 1988), with some arguing that increased competition, technological change, and occupational shifts have undermined the viability of the US’s traditional union model (Hirsch 2008; see also Jacoby 1997:256-257). Much evidence, though, suggests that union decline has largely been rooted in legal and normative changes. Dubofsky (1994) argues that the state underpinned unions’ power during the post-war period: the National Labor Relations Board (NLRB) protected workers' rights to organize and bargain collectively; courts upheld those rights against employers; and Presidents including Truman and Eisenhower pressured employers to meet reasonable demands by unions. This public protection of union power was withdrawn during the 1980s, when Reagan's dismissal of striking PATCO workers indicated that the government no longer saw unions’ demands as legitimate, and his appointment of an anti-union consultant to head the NLRB marked the withdrawal of federal support for workers' right to collectively organize. At the same time, declining profitability and growing ideological and political support for shareholder power encouraged employers to contest unions’ power within the workplace (Kochan et al. 1994; Levy and Temin 2007). Studies document a collapse in union attempts to organize new workplaces at the beginning of the 1980s, largely preventing the unionization of fresh organizations and industries (Tope and Jacobs 2009).

Where workers’ ability to secure closed employment relationships depended on their power to organize or credibly threaten to organize workplaces, then these declines in the ability of unions to organize workplaces may have contributed to declines in long-term employment. As firms faced less threat of collective action from employees, they may have been less likely to prefer established workers in the allocation of jobs, pay raises and benefits, making it less attractive for workers to stay within the organization. The reduced power of unions may also have made firms more willing to lay workers off. Where those layoffs fell on longer serviced workers or were followed by replacement hiring, such layoffs would also contribute to reduced tenure.

One way to explore how changes in union strength might have affected tenure is to exploit the 
effects of industry-level variation in unionization. Historically, industries have varied substantially in their levels of unionization, reflecting idiosyncratic factors such as the nature of the work and the era in which the industry developed (Hirsch and Berger 1984). Those unionization rates have also shown substantial effects on the behavior of all organizations in the industry, by raising the threat that non-union firms might be organized (Hirsch and Berger 1984; Podgursky 1986; Rosen 1969) and establishing industrywide norms (Western and Rosenfeld 2011). Hence, while the development of an environment that was increasingly hostile to unions will have affected all industries, we should still see substantial variation in the direct effects of that environmental change on industry-level unionization.

This inter-industry variation in unionization allows me to go beyond simply noting the coincidence of declining unionization and the reduction in tenure. Instead, I can leverage inter-industry variation in unionization rates to estimate effects of unionization on tenure. If changes in tenure reflect the declining power of unions to secure closed employment, then we should see a strong association, within and across different years, between unionization levels and worker tenure. If that association is large enough to explain the observed declines in tenure, then introducing measures of industry unionization into analyses of tenure should explain the decline in tenure over time. I hypothesize:

H1a: Industry level unionization is associated with higher tenure

H1b: Controlling for industry level unionization helps to explain the decline in worker tenure since the 1970s.

Increased foreign competition and technological change. While declining support for unionization could have reduced the power of workers to secure closed employment, other environmental changes - notably foreign competition and technological change - might have affected the willingness of employers to agree to that closure. Theories of power and bargaining suggest that parties often seek agreements that benefit the two sides equally (Skvoretz and Willer 1993; Walton and McKersie 1965): where the costs of an agreement increase for one of the parties, they are likely to seek to change that agreement. As increased environmental turbulence made closed employment relationships more costly for employers by increasing their need for flexibility and diminishing the rents available to sustain closed 
employment, it is possible that employers sought to roll back those relationships.

One source of increased environmental turbulence over the past 30 years has been foreign competition. The 1970s and 1980s saw increasing penetration of US markets by foreign competitors. Previously dominant domestic firms faced increasing competition from these imports, which accelerated during the 1990s (Berger 2005). Some industries, such as automobiles, saw domestic manufacturers’ market share fall precipitously. Others, such as textiles and apparel, radically restructured, moving production overseas (Abernathy et al. 1999). Import competition from China had a particularly important effect on wages and employment of manufacturing workers after 1990 (Autor et al. 2012).

Another source of increased environmental turbulence over the past 30 years has been the proliferation of information technology. The 1980s and 1990s saw the rapid penetration of information technology into the workplace, as computers became cheaper and more capable. In some cases, technology replaced labor in production processes. Elsewhere, technology promoted more flexible, skill intensive production processes and led to the development of new products and services (Bresnahan et al. 2002; Brynjolfsson and Hitt 2000). Research on inequality demonstrates the disruptive effects of technological change on employment, documenting how technological diffusion was accompanied by rapid changes in the returns to different skills (Autor et al. 1998).

Both foreign competition and technological change may have increased the costs to employers of long-term employment relationships, by increasing pressures for flexibility and reducing organizational rents. Where those pressures led to downsizing of recent hires or hiring freezes, it is possible that tenure could have increased as the numbers of short-tenured employees declined disproportionately. Yet where these environmental changes led to a need for entirely new skills which current employees lacked, or threatened employer profits, employers may have sought to move away from closed employment by increasing external hiring and reducing the preferences accorded to existing employees, thereby increasing voluntary turnover and reducing tenure. Where firms engaged in layoffs of long-service workers with older skills, tenure may also have declined.

As with declining support for unions, the declining costs of technology and growing 
competitiveness of foreign firms were economy-wide trends that had different effects on different industries. While technology facilitated a wholesale reorganization of some industries, others were much less affected by it; competition from imports was devastating to some industries but restrained in others (Autor et al. 2012). This variation again provides a means for testing the roles of these changes in reshaping employment relationships. If globalization and technology were responsible for the decline in long term employment, then we would expect that industry levels of imports and technology use would be associated with lower tenure, and also that increases over time in imports and technology use would explain some of the declines observed in worker tenure. I hypothesize that:

H2a: Industry levels of import competition are associated with lower tenure

H2b: Controlling for industry level import competition helps to explain the decline in worker tenure since the 1970s.

H3a: Industry levels of technology use are associated with lower tenure

H3b: Controlling for industry levels of technology use helps to explain the decline in worker tenure since the 1970s.

\section{Organizational Size as a Contingency}

The above hypotheses emphasize the role of industry conditions in shaping changes in tenure. However, the employment closure perspective outlined above suggests that declines in tenure may also have been shaped by another characteristic of employing organizations: their size.

Even during the post-war period, not all organizations fostered long term employment relationships. Instead, dual labor market theory emphasized that long-term employment relationships were predominantly a characteristic of larger organizations (Blossfeld and Mayer 1988; Tolbert et al. 1980), because those large organizations represented a more attractive target for unions (Hodson and Kaufman 1982), faced stronger social and governmental pressures to conform to a model of closed employment (Baron et al. 1986), and were better able to afford the costs of closed employment.

Those arguments have two implications for the decline in long-term employment. First, if closed employment relationships were only ever a characteristic of large employers, then their decline should 
also be most pronounced among those large employers. As a consequence, I would predict that:

H4: Over-time changes in worker tenure have been greater for larger organizations.

Second and relatedly, the environmental changes described above should have had a greater impact on larger organizations. If larger organizations were initially more vulnerable to worker demands to foster longer term employment relationships, then declines in union strength should have disproportionately affected those organizations. Similarly, if larger organizations were previously more able to afford closed employment, then the turbulence created by foreign competition and technological change may have affected them most. It is therefore likely that organizational size has moderated the effects of declining unionization and increasing import penetration and technological change on tenure. Specifically, I predict that:

H5: The effects of industry unionization, import competition and technological change on tenure are greatest for large organizations.

\section{DATA}

I test these accounts of declining worker tenure using data from the CPS. The CPS is a monthly, nationally representative survey of households that is used to assess workforce trends, including the unemployment rate. Rather than drawing a completely new sample of households every month, the CPS surveys each household eight times: once a month for four months, followed by an eight month hiatus, followed by a further four monthly surveys. Although a standard set of questions are asked each month, a variety of irregular supplements have also been used to address particular topics. I measure tenure using data from several of these supplements: a mobility supplement from February 1996, 1998, and 2000, and January 2002, 2004, 2006 and 2008; a contingent workers supplement from February 1995, 1997, 1999, 2001 and 2005; and a pensions and benefits supplement from May 1979, 1983, 1988 and 1993. ${ }^{3,4}$ I use

\footnotetext{
${ }^{3}$ Mobility supplements in1983, 1987 and 1991 also contained tenure data. However, these could not be matched to data for organizational size, so I did not use them in my analyses.

${ }^{4}$ Most workers only appear once in the data, although many of the workers who were surveyed between 1996 and 2006 appear twice in the data, as they appear in the sample in consecutive years. Additional analyses showed that including individual random effects did not change the results. I do not use that specification in this paper, as it interfered with my ability to cluster errors at the industry level which does affect my results.
} 
this data to explore changes in tenure since 1979, which is the period that is believed to have seen the greatest changes in employment relationships (Cappelli 1999; Osterman 1999) and also that saw the most sustained attacks on union power. It is also the period that prior empirical studies of changes in tenure have focused on (e.g. Hollister and Smith 2011; Neumark et al. 1999).

Although the CPS data has no information on the organizational practices that shape workers' employment relationships, it has important strengths for understanding trends in worker attachment. It offers consistent data on worker tenure going back three decades and includes detailed demographic data, allowing effects of gender, age and education to be controlled for. As a consequence, the CPS has often been used to document the decline in worker tenure (Farber 2008a; Neumark et al. 1999). The CPS also captures data on employer size and industry, allowing me to test the hypotheses laid out above.

\section{The Sample}

Because my central interest is in the causes of changing tenure, I restrict my analyses to men aged between 30 and 65 who usually work full-time. While it is also important to understand the behavior of other demographic groups, long-term employment relationships were largely restricted to men who were already established in their careers; it therefore makes sense to examine the decline of those relationships by focusing on this group. Traditionally, men have often moved jobs during the early phases of their careers (Topel and Ward 1992). In addition, married mothers became more likely to remain in their jobs during the 1980s and 1990s, even as the tenure of all other groups was falling (Hollister and Smith 2011). Restricting the sample to men eliminates these confounding effects of changing gender roles; I explore some of the other possible implications for the analysis in the discussion section. Excluding men over 65 also allows me to avoid any confounding effects of changing retirement patterns.

I also dropped those workers employed by the government. Governments face a very different institutional and economic environment than firms, and prior analyses of the CPS indicate that the tenure of public sector workers has not declined in the same way as private workers (Farber 2008a). Given that the public sector has seen neither a decline in union power nor an increase in competition, those differences between public and private sector workers are consistent with my arguments. Nonetheless, I 
omitted government workers from the analysis to avoid other effects of government employment from biasing the results. I also omitted self-employed workers and workers in the employment services industry (who are most likely to work for temporary help agencies) ${ }^{5}$ because of the difficulties of interpreting what tenure means for them. ${ }^{6}$

\section{Variables}

Worker Tenure. Worker tenure is measured in years, and is based on responses to the various tenure questions in the different supplements. The job mobility supplement asked workers "How long have you been working CONTINUOUSLY for your present employer?” The benefits supplements asked “How many years have you been working for [employer’s name]?” while the contingent work supplements asked “How long have you been working for [employer’s name]?” One problem in working with the tenure data is that people round their responses, leading to disproportionate peaks at 1 year, 2 years, 5 years and 10 years. I adopt Farber's(2008a) approach to this problem. Where respondents gave an exact number of years as their tenure, I add a random amount, uniformly distributed from -0.5 to +0.5 in order to approximate the true distribution of tenure. ${ }^{7}$

Organizational Size. The 1979, 1983, 1988 and 1993 benefits supplements contained data on both tenure and organizational size. I gathered organizational size data for other years by matching in size data from responses to the "March supplement” of the CPS, which respondents answered in a different month. Madrian and Lefgren (1999) provide details of this matching process. Because not all respondents could be contacted in each wave of the survey, and some (around 1-3\%) might have moved jobs between waves, such matching has the potential to introduce bias. Supplementary analyses demonstrated very similar time trends for matched versus unmatched data, though. Further details are available in an online

\footnotetext{
${ }^{5}$ I am unable to identify other contingent workers, such as independent contractors in most years of the data. Supplementary analysis using the contingent worker supplements suggested that including those workers has little effect on my results, though.

${ }^{6}$ I reran key analyses using all male workers under the age of 65 . The results were very similar to those presented here. Time trends for women are different to those for men, although the effects of organizational size and unions are similar for men and women.

${ }^{7}$ I also explored whether to use tenure or log tenure as a key dependent variable. Comparison of results showed that analysis using tenure fit the data better than analysis using log tenure. Qualitatively, the results of analyses using the linear and logged variable gave very similar results.
} 
appendix to this paper.

The March supplement asked workers “Counting all locations where this employer operates, what is the total number of persons who work for ...'s employer?” The 1979, 1983 and 1988 benefits supplements similarly asked “How many employees are employed at all locations?” with a wider range of possible responses. I consolidated the different response categories into three: under 25; 25-999 workers; and $1000+$.

One concern with this variable is that workers may often not know their employer's size. The limited number of response categories should mitigate this problem: most workers are likely to know whether their employer has fewer than 25 employees or more than 1000 employees. To the extent that some responses are still inaccurate, that would bias against finding effects of size. This measure also cannot test differences between the behavior of organizations with 100,000 employees versus 1,000 employees. Despite these limitations, much research has used the CPS data on firm size, finding strong effects of this variable on wages (e.g. Brown and Medoff 1989; Hollister 2004).

Unionization. Consistent with my arguments, I measure unionization at the industry level (I break out union and non-union members in supplementary analyses). The earnings supplement of the CPS asks workers whether or not they are members of a union. Because the earnings supplement is only implemented in the fourth and eighth month a household is interviewed, only one quarter of workers are asked this question each month. I matched answers for the other workers into the data using earnings supplements from subsequent months of the CPS. For each year and for each three-digit industry as defined by the census for that year, I then calculated the percentage of all workers in that industry (including women and those outside the age range of my primary sample) who were members of a union, using the CPS weights to adjust for sampling differences.

Import penetration. I calculated import penetration using industry-level data on the gross value of imports for 1979 to 2006 (Feenstra et al. 2002). These import data are only reported for commodity and manufacturing industries, so the analyses using this data are restricted to these industries. These are the industries that were most exposed to foreign competition, though: if foreign competition affects tenure, it 
is in these industries that we would see the effects. I aggregated these data, which are identified by SIC and NAICS codes, into industries as defined by the census (the census uses its own coding scheme. I constructed crosswalks using tables from the Census (2001) and Unicon Research (2005)). I then calculated import penetration rates by dividing total industry imports by gross industry output, taken from the National Income Product Accounts.

Investments in new technology. I calculated industry-level spending on information technology using data from the Input-Output tables of the National Income Product Accounts. Unlike the other measures, these data are only released every five years (I used data for 1977, 1982, 1987, 1992, 1997 and 2002). I matched employment data with the most recent data on IT spending. Again, industries defined by commodity codes (1977-1992) and NAICS (1997 and 2002) were matched to census industry codes. I then calculated IT intensity by dividing each industry’s total purchases of IT specific goods and services by the total purchases of those industries in that year. ${ }^{8}$ One limitation of the Input-Output tables is that they aggregate all of wholesale and retail industries into just two categories. I therefore lack detailed industry-level data for wholesale and retail industries, and they are omitted from analyses using this data.

Controls. I controlled for individual-level attributes that might affect tenure and have changed over time. These controls include age, age squared and dummies for completion of high school, associate’s degree, bachelor's degree, and some postgraduate education. I also controlled for occupation: I translated occupation categories from all periods into a modified set of the 2002 census categories (this set of dummies splits work into 24 different occupations. I combined three professional work categories because of difficulties in matching these across years). I also controlled for unemployment, because of concerns that turnover rates vary systematically with unemployment (Hom and Kinicki 2001). I include a measure of the January unemployment level in each worker's state in each year in the analyses.

The full data set contains 138,612 observations, although the numbers in the analyses vary due

\footnotetext{
${ }^{8}$ Before 1997, the specific IT goods and services were: calculating and accounting machines; electronic computers; computer peripheral equipment and computer and data processing services. After 1997, they were: computer and peripheral equipment manufactures; internet service provision; internet publishing and broadcasting; computer systems design and related services.
} 
both to missing data and to my analyses of subsamples. Table 1a gives descriptive statistics for the main variables. Table $1 \mathrm{~b}$ gives annual averages of unionization, import penetration and technology intensity, both by industry and by worker. We see substantial changes in all three measures from 1979 to 2008 .

\section{ANALYTICAL APPROACH}

The goal of my analyses is to understand how industry characteristics might help to explain changes in tenure over time. To that end, I conduct OLS regressions with tenure as the dependent variable. The unit of analysis is always the individual. Conducting analysis at that level allows me to control for changes in the composition of the workforce as workers got older and more educated and as the occupational distribution changed. I cluster standard errors at the industry level because my key independent variables are at this level, and errors may not be independent within industries. Observations are weighted by the supplement weights in the CPS, except in fixed effects analyses.

I assess changes in tenure over time using a linear year variable (I also conducted analyses using the more flexible form of dummies for each year. Those analyses, which are available in an online appendix, depict a largely monotonic trend in tenure and showed substantively similar results to the linear specification. In the interests of space, I display the simpler, linear trend here). A significant negative effect of year on tenure indicates that tenure declined over time, holding worker demographics, occupation and local unemployment constant.

I then seek to explain that year effect in my analyses, by adding industry characteristics as a control. If the year effect declines once industry characteristics are controlled for, it suggests that part of the change in tenure reflects changes in those industry characteristics. In a statistical sense, this test functions as a test of mediation (Baron and Kenny 1986): Table 1b demonstrates that time trends predict the mediating variables of industry characteristics; I then explore whether those mediating variables predict tenure, and whether including them in the analyses attenuates the effects of time on tenure.

\section{RESULTS}

Figure 1 graphs the average tenure of men aged 30-65 by year, broken out by employer size. The graph demonstrates striking differences in tenure trends across the different employer sizes. Average 
tenure in the smallest organizations actually increased; tenure in medium sized organization fell very slightly; but there was a strong decline in average tenure in large organizations, from a little over 14 years in 1979 to around 10 years in 2008. Underlying this trend is a particularly large increase in short term employment relationships. Among the employees of large organizations in my sample, the proportion of workers with less than three years of experience increased from $18 \%$ in 1979 to $28 \%$ in 2008.

Another way of comparing these trends is to examine the gap in tenure between the largest and smallest organizations. In 1979, the average tenure of men aged 30-65 was 92\% higher in organizations with more than 1000 employees than average tenure in small organizations; by 2008, that gap had declined to just 22\%. The figure therefore offers strong support for Hypothesis 4, that changes in tenure have been greatest for larger organizations.

\section{Main Analyses}

Table 2 presents the main regressions of tenure on time and industry characteristics. I first present the trends for all organizations (Model 1) and then for the three different sizes (Models 2-4). The models replicate Figure 1. There is a significant effect of year on tenure among all organizations (Model 1). Multiplying the coefficient by 29 years suggests a decline in tenure of 1.7 years from 1979 to 2008. This effect is much stronger among employees of organizations with greater than 1000 workers (Model 4), where the coefficient implies a decline in tenure of 3.9 years over the same time period. By contrast, tenure increased slightly in the smallest organizations (Model 2) and declined very little in medium sized organizations (Model 3). Differences across the coefficients are significant, supporting Hypothesis 4.

Models 5-9 then test H1-3, exploring whether changes in industry characteristics might explain some of the decline in tenure. In these analyses, I restrict the sample to employees of large organizations only. The earlier models show that tenure changes were restricted to those organizations. It therefore makes most sense to explore the causes of changing tenure among large organizations (analyses in the online appendix show very similar results among the employees of all organizations).

Model 5 provides strong evidence for H1a and H1b, which related declines in industry-level unionization to declines in tenure. Industry-level unionization has a highly significant effect on tenure, as 
proposed by H1a. According to the estimate, moving from the $10^{\text {th }}$ percentile of industry unionization rates $(0.012)$ to the $90^{\text {th }}$ percentile $(0.32)$ increases tenure by 3.3 years. The unionization variable also explains much of the change in tenure, as proposed by H1b, with the year coefficient declining by more than half from Model 4 to Model 5. A Sobel tests (Baron and Kenny 1986) for mediation of the change in tenure is also highly significant $(\mathrm{z}=-8.2)$. If the relationship between unionization and tenure is causal, then these results indicate that the average tenure of men aged 30-65 in large organizations would have declined by around half the amount that it did if unionization had stayed constant from 1979 to 2008 .

Models 6 and 7 then test H2a and H2b, which related import competition to declines in tenure. Because I only have data on imports for manufactures and commodities, I first confirm the basic time trends within that restricted subsample (Model 6). I find that the year effect is smaller in those tradable industries than in the full sample (Model 4), even though they should have been most exposed to global competition. Adding the import measure in Model 7, I find no support for H2a. Import penetration is not significantly associated with tenure. Similarly, including import penetration in the analysis does not significantly alter the year effect, offering no support for H2b.

Models 8-9 then test H3a and H3b, that use of information technology explains declines in tenure. Again, I only have data on a subset of industries (although there are no reasons to believe that the excluded sectors of wholesale and retail have behaved very differently from the rest of the economy). In Model 8, I confirm that time trends within the restricted subsample are similar to the economy as a whole. I add the technology intensity variable in Model 9, finding no support for H3a. Technology intensity does not predict tenure. Nor does including this variable affect the year coefficient, contrary to H3b. ${ }^{9}$

Models 10-12 then provide a formal test of Hypothesis 5, that the effects of environmental pressures are greater for large firms. The hypothesis is confirmed for unionization: the effects of industry unionization on tenure are significantly higher for large organizations (interaction coefficient $=7.5, \mathrm{z}=$ 9.8 in Model 10). This effect helps to explain why tenure has changed most in large organizations. I do

\footnotetext{
${ }^{9}$ In supplementary analyses not reported here, I also explored whether these variables might have affected mobility during some portion of the period studied, without having long-term effects. Interacting the independent variables with year effects, I found little evidence for time varying effects of these pressures.
} 
not find similar effects for technology or import penetration, although Model 12 suggests that technology investments are associated with lower tenure in smaller employers. Since tenure has not fallen in these organizations, such a finding does not help explain why tenure has declined overall.

These analyses show that controlling for industry unionization explains a substantial proportion of the decline in tenure that has taken place over the last 30 years, and that these declines have been particularly strong in large organizations. I probe these effects further in the remainder of this section.

\section{Further Analysis of Unionization Effects}

I have argued that unionization rates affect worker tenure because they help workers to bargain for the kinds of closed employment relationships that foster long-term employment. I have also argued that employment relationships often reflect industry-level pressures, as even nonunion firms in heavily unionized industries respond to the threat of unionization. There are, however, a number of alternative explanations for the correlation between unionization in tenure. I explore those effects in Table 3. I again restrict my analyses to employees of large organizations.

First, I explore the effects of wages. One explanation for the effects of industry unionization on tenure is that wages are higher in unionized industries (Freeman and Medoff 1981), and that those higher wages reduce turnover. I calculated industry wage premia by regressing weekly earnings on age, education and occupation in each year for the workers in the sample. I aggregated residuals from these regressions by industry to create a yearly measure of the industry wage premium. Model 1 confirms that industry wage premia correlate with tenure, but have a very small effect in explaining mobility trends (year effect declines from -.133 in Table 2 Model 4 to -.123 in Table 3 Model 1).

I also explored the effects of long-term industry growth rates: faster growing industries should have lower unionization rates, because new establishments were less likely to be organized by unions (Ferguson 2008). It is therefore possible that the strong relationship between unionization rates and the decline in tenure reflects lower tenure among industries that have grown more rapidly over the last 30 years. I tested for such an effect by including a variable for how much each industry had grown between 1979 and the observation date. For each year and industry, I used the CPS data to calculate the 
proportionate growth of the industry since 1979 (using data on all workers, rather than just men aged 30 to 65). Model 2 shows that tenure is indeed lower in industries that grew more over the last 30 years, but that the effects of this growth explain very little of the decline in tenure as measured by the year effect. The effects of unionization remain highly significant when controlling for wages and growth since 1979 (Model 3), and do not, therefore, simply reflect the differences between new and old industries.

I also explore whether unionization affects workers throughout an industry, or whether it simply makes union members reluctant to quit their workplaces. I do this by splitting the sample into union members and non-union members. Models 4 and 5 show that tenure has declined much less for union members than non-union members, consistent with my arguments. Models 6 and 7, though, show that the level of industry unionization has similar (and substantial) effects for both union and non-union members. These results confirm that unionization affects the entire industry, consistent with recent work on inequality (Western and Rosenfeld 2011).

I also examined the role of within- versus between-industry changes in driving the effects of unionization. Thus far, I have proposed a very simple relationship between unionization and closed employment: where unionization is high, closed employment relationships are more likely, leading to higher tenure. In reality, this relationship is likely to be complicated by institutionalization effects. Organizational and industry practices often demonstrate substantial inertia (Stinchcombe 1965). Tenure may therefore respond only gradually to declines in unionization within an industry.

One way to explore these inertial effects is to divide the effects of unionization into a withinindustry effect of declining unionization, and a between-industry effect which represents the way that levels of unionization within different industries are associated with different levels of tenure. It is likely that declines in unionization have affected tenure through both of these effects: tenure may have fallen as unionization fell within an industry; tenure may also have fallen as employment shifted from more unionized industries with higher tenure towards less unionized industries with lower tenure. Both processes are consistent with the theory laid out above: after all, an important reason why growing industries have had lower unionization is that they have grown up during an era that is hostile towards 
unions. Where there is substantial within-industry inertia, we might also expect the between-industry effects of unionization to be larger than the within-industry effects.

I explore the relative balance of these within- and between- industry effects in Models 8 and 9 of Table 3, where I include industry-level fixed effects in the analysis (this requires creating a consistent set of industry categories across the time period. I drop a small number of observations that could not be classified into those industries). Including those fixed effects (Model 8) substantially reduces the size of the year coefficient (comparison with Model 4 in Table 2), suggesting that around $40 \%$ of the decline in tenure within large employers between 1979 and 2008 reflected a shift in the workforce from industries that generally have higher tenure to industries that generally have lower tenure. Model 9 demonstrates a marginal within-industry effect of unionization on tenure: controlling for industry fixed effects, industry unionization continues to have an effect on tenure, albeit only at the $10 \%$ significance level, and is associated with a further decline in the year effects (analyses in the online appendix that use the more complete specification of year dummies show an effect of unionization that is significant at the $5 \%$ level and that including unionization had a more substantial effect on the time trend). The coefficient on unionization is smaller than the coefficient in the pooled OLS regression (Model 5, Table 2), though, suggesting that declining unionization has smaller within-industry effects than between-industry effects. In supplementary analyses in the online appendix I also explored how changes in tenure and effects of unionization varied between blue collar workers, service and clerical workers, professional and technical workers, and managerial workers. I found very similar time trends across the different groups, although professional and technical workers demonstrated the smallest declines in tenure. I also found that industry unionization had significant effects on tenure in all occupations, with the largest effects on service workers. The effects of unionization also explained more of the decline for blue collar workers than for other occupations, reflecting the way that unionization fell much further in industries employing blue collar workers. The far reaching effects of unionization on all occupations, including managerial workers, most likely reflects the way that employment practices for frontline workers often spill over to managers because of institutionalization processes and the need to maintain internal equity (Colvin et al. 
2001; MacDuffie 1996).

\section{Determinants of Unionization}

Given the important role of unionization in explaining declines in tenure, it is valuable to ask what determines unionization. In particular, could changes in unionization themselves be driven by factors such as globalization, technological change, or pressures on profitability? I explore this question in Table 4, where I present logit analyses using individual union membership as the dependent variable. I include all employees (including women and younger and older men) in the analysis.

Consistent with Table 1B, Model 1 shows a significant negative effect of year on the odds of a worker being a union member. Employees of larger organizations are also more likely to be unionized. I find no evidence that unionization is lower in industries with more import penetration (Model 3), or higher technology intensity (Model 5). In Model 6, I include industry return on assets (winsorized at the $1^{\text {st }}$ and $99^{\text {th }}$ percentiles), taken from Compustat. Again, I find no effect of profitability pressures on unionization. I do find that unionization is significantly lower in industries that have grown more rapidly, consistent with accounts that emphasize the problems of organizing new establishments (Model 7). These analyses suggest that declines in union membership cannot be directly traced to pressures from import competition, technology or profitability. Instead, the results are consistent with accounts of union decline rooted in the difficulties of organizing new establishments in a hostile legal and normative climate.

\section{Voluntary Turnover, Involuntary Turnover and Organizational Growth}

At the beginning of the paper, I noted that declines in tenure could be driven by three processes: organizational growth, replacement hiring following voluntary turnover, and replacement hiring following involuntary turnover (the effects of turnover will also partly depend on the seniority of the workers who leave). The analyses thus far have not been able to distinguish between these different sources of changing tenure. I can, however, shed some light on this question through supplementary analyses.

Evidence on Layoffs. Although most of the CPS supplements that I use do not describe why workers moved jobs, data on some forms of involuntary turnover are included in a "Displaced Worker Survey” which has been asked every second year from 1984 (Farber 2008b). This survey asks whether, 
during the last 3 years, a worker lost a job because their plant was closed, their employer went out of business, there was a layoff, their position was abolished, or similar reasons. ${ }^{10}$ This data can therefore be used to examine whether the trends in and determinants of layoffs are similar to tenure. It is worth noting that these questions do not count workers who were dismissed for cause; Oyer and Schaefer (2000) estimated that these dismissals accounted for only around $20 \%$ of involuntary terminations of young men between 1987 and 1994, and declined slightly following the passage of the Civil Rights Act in 1991. Based on the CPS, layoffs themselves represent around $1 / 4$ to $1 / 3$ of all separations, suggesting that dismissals play a very small role in shaping mobility.

Matching industry characteristics to this layoff data is more complex than for the tenure data. One possibility is to match in the characteristics of the industry that respondents were in at the time of the survey (this is the same as the industry that the workers were laid off from in about $40 \%$ of cases). This helps us to identify the industries in which falls in tenure partly reflect the hiring of recently laid off workers. Alternatively, it is possible to match in the characteristics of the industry that workers were laid off from, to explore the determinants of layoffs. Such an analysis lacks an accurate control group though; instead, I assume that all workers who were not laid off are still in the same industry that they were in three years ago. Since neither analysis is perfect, I present both. In Table 5, I present logit analyses where the dependent variable is whether the worker has been laid off within the last three years. Because I lack data on organizational size for the early years of the data (and never have data on the size of the organizations that workers were laid off from), I look at employees of all firms.

The analyses of layoffs demonstrate a very different pattern to the tenure analyses. I do not find strong evidence of an increasing rate of layoffs (see also Davis 2008; Farber 2008b). ${ }^{11}$ I find evidence that workers in unionized industries are less likely to have been laid off within the prior three years. I also find

${ }^{10}$ The wording of this question changed slightly in 1992. Also, prior to 1992 workers were asked if they had lost their job in the last five years. However, information on when they lost their job can be used to construct a consistent measure of whether a worker was laid off during the last three years.

${ }^{11}$ Supplementary analyses found some evidence that the rate of layoffs has increased once local unemployment is controlled for (tenure trends, by contrast, are unaffected by unemployment controls). Because local unemployment may be as much an effect of layoffs as a cause, I do not control for it in the main analyses reported here. 
that workers are significantly less likely to have been laid off from unionized industries, although the effect is weaker. Unlike changes in tenure, I also find that industry import penetration and technology intensity significantly predict layoffs, both for the industries that workers are currently in and the industries that they were laid off from.

I also ran some additional analyses (available in the online supplement) where I explored whether the rate of layoffs of workers from an industry have been associated with declines in tenure. Because I did not have layoff data for all years, I had to match many observations to layoff data from adjacent years (hence, I proxied industry layoffs in the three years to 1983 with data from 1984. For the other odd numbered years, I used the layoff data from the most recent year). That rough analysis found no significant relationship between layoffs of workers from an industry and the tenure of workers in that industry. The weak correlation between tenure and layoff rates, the somewhat different time trends in involuntary turnover versus tenure, and the way that they are explained by somewhat different industry variables suggests that layoffs may have played a limited role in driving declines in tenure.

Effects of Industry Growth Rates. In further analysis in the online appendix, I also analyzed how industry growth rates might have affected my findings. Average tenure rates reflect fluctuations in growth rates over long periods of time, making it difficult to fully control for effects of industry growth in tenure regressions. I overcame this problem by dichotomizing tenure, to look at whether the worker had been hired within the prior three years (around 30\% of the sample have less than three years tenure). I then created a control for the rate of industry employment growth during the prior three years using the CPS. Logit analyses replicated the prior results: the probability that a worker had less than three years of tenure increased significantly over time, and changes in unionization rates explained essentially all of that increase. Although shorter tenure was associated with industry growth, introducing the growth variables had very little effect on the results. I also explored the effects of intra-industry turbulence, using data from the Statistics of US Business (SUSB) on the number of jobs destroyed by establishment contraction and death and the number of jobs created by establishment birth and expansion. Again, while I found some evidence that intra-industry turbulence reduces tenure, I did not find that those processes explained the 
increase in short-term employment or the effect of unionization. These analyses confirmed that changes in the rate of inter-and intra-industry reallocation of workers have played little role in driving over-time declines in tenure.

\section{DISCUSSION}

The marked decline in the length of employment relationships represents one of the most important changes in the nature of employment, careers, and organizations to have taken place over the last three decades. A foundational assumption of the post-war employment model for large firms was that employment relationships represented an enduring bond between firm and worker. The years since 1979, though, have seen the growth of a less stable, more transactional employment model. Tenure has declined by $30 \%$ among prime aged men, with particular increases in the proportions of men with less than three years of tenure. While much work has gone into documenting this decline in tenure, there has been little systematic analysis of its causes. This study brings new evidence to bear on this question.

I argue that long term employment relationships arose as a consequence of workers’ efforts to secure closed employment relationships that provided incumbent employees with preferential access to rewards and opportunities. I then explore why workers’ ability to secure those closed employment relationships might have declined, proposing a role for declining union strength in the face of a more hostile legal and political environment, and for an economic environment that raised the costs of closed employment to employers. I test those explanations by examining how declines in tenure reflect changes in particular industry characteristics. In doing so, I establish a number of new empirical findings.

First, I find that declines in tenure have been strongly associated with changes in industry-level unionization: including unionization in my analyses explained around one half of the decline in tenure within large organizations between 1979 and 2008. That unions are associated with longer tenure is well known (Pfeffer 1983). Yet my findings extend this simple association in important ways. My results provide evidence that declines in union membership have powerfully affected the duration of employment relationships. While other work has documented the decline in unionization (Kochan et al. 1994), prior work has not shown how that decline is associated with the fall in worker tenure. 
Supplementary analyses shed further light on the pervasive effects of industry-level unionization on tenure. I found that industry unionization levels have strong effects on union and non-union workers alike, as well as workers in all major occupational groups. These pervasive effects suggest that unionization may affect the institutionalization of different practices at the industry level, and is consistent with other research on the role of unions on wages and working conditions (Colvin et al. 2001; MacDuffie 1996; Western and Rosenfeld 2011). Although I find that changes in unionization affected tenure both within and across industries, the stronger across-industry effects also point to a role for institutionalization processes in shaping the effects of unions on tenure.

It is important to acknowledge the limits to what we can infer from the present study. I am able to establish a very strong relationship between changes in unionization and changes in tenure. This result is consistent with histories of the development of long term employment relationships which suggest a strong role for unionizations in promoting employment closure (Baron et al. 1986; Jacoby 1985). I also find little evidence to support many of the major alternative explanations for the findings, such as the idea that declining unionization is itself a response to technological change or globalization. Nonetheless, the nature of the data that I draw on means that my evidence is primarily correlational. I argue that declines in union power reflected a hostile legal and normative climate. Although studies of union organizing supports this argument (Tope and Jacobs 2009), it is possible that other processes might be driving both declines in unionization and changes in tenure. One such candidate is the growth of new establishments. Given that union decline largely reflected the inability of unions to organize new establishments, establishment age should be correlated with declining union power, but is beyond my ability to measure. I am able to show that the mechanical effects of establishment growth do not explain declines in tenure, and that my results do not simply track the growth of new industries, but it is possible that younger establishments are less likely to offer closed employment relationships. The very strong correlations between industry unionization and tenure, though, suggest that a central reason why younger establishments would be less likely to offer closed employment is that they are emerging during a period when unions are weaker. Another possible omitted variable is shareholder power. Prior research has 
associated shareholder power with layoffs (Budros 1997; Fligstein and Shin 2007; Jung 2011), but it is a construct which is difficult to effectively measure using industry-level data. Where shareholder pressures did affect tenure, they are likely to be complementary to the effects of declining unionization, providing another route whereby power shifted from workers to employers. Overall, then, this paper cannot prove a conclusive role for union decline in shaping changes in tenure. Nonetheless, the evidence points strongly to union decline as the most promising avenue for further study of declines in worker tenure.

I also show that declines in worker tenure have been concentrated among large organizations: in 1979, workers in large organizations had nearly double the tenure of employees of small organizations; by 2008, the tenure gap between large and small organizations was just 22\%. Dual labor market theory argued that large organizations had longer employment relationships because they were more susceptible to the exercise of collective worker power and legitimacy pressures (Baron et al. 1986; Hodson and Kaufman 1982). It appears that the dilution of those pressures in recent decades has also primarily affected large organizations. As the worker pressures that sustained the dual labor market have lost their potency, so important differences between large and small organizations are fading away.

Almost as interesting are the hypotheses that are not supported. I argued that workers’ declining tenure could reflect increased environmental turbulence, which raised employers' costs of maintaining long term employment relationships. Yet variables measuring the key changes that US organizations have faced - increased foreign competition and technological change - had very little effect on either worker tenure or its changes over time. It is possible that the lack of results might reflect weaknesses in the measures. For example, problems in matching external industry data with the CPS could create measurement error. That said, the ability of both variables to predict layoffs should reassure us about their accuracy.

As I noted at the beginning of the paper, changes in tenure could reflect organizational growth, voluntary turnover, or involuntary turnover. My supplementary analyses were able to rule out growth as a cause of increasing tenure, showing that declines in tenure have not been driven by increases in interindustry restructuring or a more rapid rate of organizational growth and decline within industries. Because 
the data that I use do not tell us why workers left their prior jobs, it is more difficult to fully tease apart the relative roles of voluntary versus involuntary turnover in driving changes in tenure. Moreover, my theory development suggests that both kinds of turnover may have been affected by declines in employment closure, as workers saw less advantage to remaining with their employers and faced fewer protections against layoffs. Given that the layoff data do not include proper industry risk sets, lack data on dismissal for cause and do not break out employers by size, my supplementary analyses of layoffs should be treated with some caution. Nonetheless, I believe that those analyses suggest that voluntary turnover may have played the dominant role in driving tenure declines since 1979. The data indicate that the rate of layoffs was largely static during the same period that tenure was falling, and that layoffs were often associated with different industry conditions than declines in tenure: import competition and technology are strongly associated with layoffs but not changes in tenure. Nor do layoffs from an industry appear associated with tenure in that industry, suggesting that layoffs within industries have played a limited role in reducing tenure. Although not conclusive, these analyses suggest that declines in worker tenure may represent a distinct phenomenon from the downsizing with which they are often linked, and that changes in tenure may often reflect increased voluntary turnover.

I have also noted that the effects of turnover depend in part on the seniority of the workers who leave the organization. Unfortunately, the cross-sectional data that I use is not well suited to exploring trends in the mobility rates of workers with different tenure. Some studies have constructed synthetic cohorts to explore the relative retention rates at different tenure levels, and suggest a particular increase in mobility of more highly tenured workers (Kambayashi and Kato 2012; Neumark et al. 1999). Such an approach is not well suited to the analysis of the highly disaggregated categories that I use here, though.

The suggestion that declines in tenure are due to increases in voluntary mobility is consistent with my theory, which argues that an important effect of unionization was to allow employees to secure improved rewards and opportunities within the firm, reducing their incentives to move organizations. An important question for future work is whether such increased turnover reflects declining opportunities for mobility within firms, reduced returns to seniority or benefits for workers, or increased ease of mobility 
into new organizations. Some research provides suggestive evidence on this topic. For example, Hollister (2004) finds that the premium received by employees of large firms declined during the 1980s and 1990s, consistent with a reduction in the rewards offered by large firms to their workers. DiPrete et al (2002) also find that the returns to tenure have declined for some groups of workers. Future research should explore how the wage profiles of employees in larger organizations have changed.

Future work should also look at changes in employment practices. The nature of the data used in this study did not allow me to directly measure how organizations foster long-term employment relationships. The concentration of tenure declines within large organizations supports the argument that those declines are rooted in changes to closed employment relationships, since the protection of existing workers was only ever a feature of those large organizations (Blossfeld and Mayer 1988). Future work that examines the adoption and abandonment of specific practices is important for shedding further light on the firm-level processes that have mediated declines in tenure. A further limitation of the data is that I have very little organization-level information on employers. Longitudinal data on the tenure of workers within identified organizations would allow for the analysis of how specific actions, such as mergers or shareholder activism, have affected tenure.

A further important area for future study is how tenure has changed within different demographic groups, and what interaction there might be between those groups (see Hollister and Smith (2011) for a discussion of gender differences). A particularly interesting question is whether women's gains in employment stability could have come at the expense of men. For example, if the stability of men's jobs partly reflected their employment in more privileged, core firms, then it is possible that displacement of men from those firms by women might partly account for declining male tenure. I carried out some preliminary analyses that cast doubt on such an account. While I found that men's tenure was higher in more male dominated industries, that effect appeared to be entirely explained by unionization levels. Furthermore, an influx of women into an industry (which we might expect to displace men from core 
firms within it) was associated with an increase in men's tenure, rather than a decline. ${ }^{12}$ It is also worth noting that the convergence in tenure across different employer sizes suggests that declines in long term employment reflect an abandonment of closure practices by core firms, not declining male access to the core. Nonetheless, this paper's focus on trends in male tenure needs to be complemented by a more systematic examination of how and why the tenure of demographic groups differ and interact.

A further question is what other influences might also have shaped changes in voluntary mobility. My analyses suggest that declines in unionization may explain a large proportion of the decline in tenure, but not all of it; other processes may well be in play. Based on my results, I can shed light on some potential explanations for why workers might move jobs more than they used to. For example, although it is possible that information technology has increased the importance of general skills versus firm specific skills, such an account suggests bigger effects in industries that make larger technology investments. I find no such effect. It is also possible that general cultural trends have reduced the importance of long term employment for workers. That said, it is striking that declines in tenure are restricted to large organizations; we might expect cultural trends to have more even effects across different kinds of organizations. What other processes may be affecting tenure trends remains an open question.

\section{Implications for Theory}

In addition to explaining the causes of the changes we have seen in the US labor market, this paper also has implications for our broader understanding of employment relationships. Perhaps most important, the paper contributes to our understanding of the way that the shifting balance of power between workers and employers, and changes in the ability of workers to collectively organize in particular, have affected employment relationships and careers. While scholars have explored the effects of union decline on income inequality (Card 2001; Western and Rosenfeld 2011), or explored how the relative power of workers and employers affects promotion prospects among managers and professionals (Dencker 2009; Phillips 2001) they have said much less about how shifts in the power of workers versus

\footnotetext{
${ }^{12}$ This effect may reflect reduced entry by men into the industry, so that earlier entrants made up a higher proportion of male employees. I am grateful to a reviewer for pointing this out.
} 
employers has shaped other facets of the employment relationship. My findings therefore emphasize the importance of paying more attention to societal power as we seek to understand how employment has changed, rather than the oft cited effects of technology and globalization.

Such a focus has particular implications for how we think about the future of employment relationships, suggesting in particular that worker tenure will not increase again unless we see a substantial increase in the power of workers to influence the structure of employment relationships. This study suggests that long term employment relationships were dependent on an institutional structure that supported the exercise of collective worker power in favor of closed employment. There is very little evidence of a resurgence in institutional support for worker power that would allow a return of closed employment. Some scholars have pointed to the counterproductive consequences that may stem from employers’ naked exercise of power, as they erode the trust necessary for knowledge intensive production (Adler 2001). It is therefore conceivable that we will see a re-emergence of long-term employment relationships in support of modern production techniques. It is hard, however, to see evidence of such a re-emergence in the existing data.

It is worth noting, though, that collective organization is not the only source of power for workers. As unionization has become more difficult, the individual threat to leave is likely to be a greater constraint on employers' practices. It seems unlikely that such a source of power will take workers back toward closed employment practices, since any move towards closure automatically undermines the threat to leave. Nonetheless, it is possible that different sources of power will shape employer practices in new ways. An important topic for research therefore is how employers respond to tight labor markets.

The strong empirical relationship between unionization and long term employment may also have implications for the consequences of declining tenure. Increased mobility could benefit workers by giving them increased opportunities to find jobs that match their needs and abilities. Yet it could also reflect worsening conditions for workers, as firms offer fewer opportunities for internal mobility or fewer rewards to more senior employees. That tenure has declined most where organized labor is weakest offers some support for the latter, more pessimistic viewpoint. Long term employment relationships existed 
where workers were best placed to advance their own interests. The move towards more short-term employment may therefore disproportionately benefit employers. 


\section{REFERENCES}

Abernathy, F.H., J.T. Dunlop, J.H. Hammond, D. Weil. 1999. A stitch in time: lean retailing and the transformation of manufacturing - lessons from the apparel and textile industries. Oxford University Press, New York.

Adler, P.S. 2001. Market, Hierarchy, and Trust: The Knowledge Economy and the Future of Capitalism. Organization Science 12(2) 215-234.

Althauser, R.P., A.L. Kalleberg. 1981. Firms, Occupations and the Structure of Labor Markets: A Conceptual Analysis. I. Berg, ed. Sociological Perspectives on Labor Markets. Academic Press, New York, 119-149.

Arthur, M.B., D.M. Rousseau. 1996. The boundaryless career : a new employment principle for a new organizational era. Oxford University Press, New York.

Autor, D.H., D. Dorn, G.H. Hanson. 2012. The China syndrome: Local labor market effects of import competition in the United States. Unpublished Manuscript.

Autor, D.H., L.F. Katz, A.B. Krueger. 1998. Computing Inequality: Have Computers Changed the Labor Market? The Quarterly Journal of Economics 113(4) 1169-1213.

Baker, G., M. Gibbs, B. Holmstrom. 1994. The Internal Economics of the Firm: Evidence from Personnel Data. The Quarterly Journal of Economics 109(4) 881-919.

Baron, J.N., F.R. Dobbin, P.D. Jennings. 1986. War and Peace: The Evolution of Modern Personnel Administration in U.S. Industry. The American Journal of Sociology 92(2) 350-383.

Baron, R.M., D.A. Kenny. 1986. The moderator-mediator variable distinction in social psychological research: Conceptual, strategic, and statistical considerations. Journal of personality and social psychology 51(6) 1173-1182.

Bauman, Z. 1998. Work, consumerism and the new poor. Open University Press, Buckingham. Baumol, W.J., A.S. Blinder, E.N. Wolff. 2003. Downsizing in America. Reality, Causes, and Consequences. Russell Sage Foundation, New York.

Berger, S. 2005. How we compete: what organiztions around the world are doing to make it in today's global economy. Doubleday, New York.

Bernhardt, A., M. Morris, M.S. Handcock, M.A. Scott. 2001. Divergent paths: economic mobility in the new American labor market. Russell Sage Foundation, New York.

Bidwell, M.J. 2011. Paying More to Get Less: Specific Skills, Incomplete Information and the Effects of External Hiring versus Internal Mobility. Administrative Science Quarterly 56(3) 369-407.

Blossfeld, H.-P., K.U. Mayer. 1988. Labor Market Segmentation in the Federal Republic of Germany: An Empirical Study of Segmentation Theories from a Life Course Perspective. European Sociological Review 4(2) 123-140.

Bresnahan, T.F., E. Brynjolfsson, L.M. Hitt. 2002. Information Technology, Workplace Organization, and the Demand for Skilled Labor: Firm-Level Evidence. The Quarterly Journal of Economics 117(1) 339-376.

Brett, J.M., L.K. Stroh. 1997. Jumping Ship: Who Benefits from an External Labor Market Career Strategy? Journal of Applied Psychology 82(3) 331-341.

Brown, C., J. Medoff. 1989. The Employer Size-Wage Effect. The Journal of Political Economy 97(5) 1027-1059.

Brynjolfsson, E., L.M. Hitt. 2000. Beyond Computation: Information Technology, Organizational Transformation and Business Performance. The Journal of Economic Perspectives 14(4) 23-48. Budros, A. 1997. The New Capitalism and Organizational Rationality: The Adoption of Downsizing Programs, 1979-1994. Social Forces 76(1) 229-249.

Budros, A. 1999. A Conceptual Framework for Analyzing Why Organizations Downsize. Organization Science 10(1) 69-82.

Cappelli, P. 1999. The new deal at work : managing the market-driven workforce. Harvard Business School Press, Boston.

Cappelli, P. 2000. Market Mediated Employment: The Historical Context. M. Blair, T.A. Kochan, eds. 
The New Employment Relationship. Brookings.

Cappelli, P. 2008. Talent on demand : managing talent in an age of uncertainty. Harvard Business Press, Boston, Mass.

Card, D. 2001. The Effect of Unions on Wage Inequality in the U.S. Labor Market. Industrial and Labor Relations Review 54(2) 296-315.

Census, B. 2001. Industry Code Crosswalk.

Colvin, A., J. S. , R. Batt, H.C. Katz. 2001. How high performance human resource practices and workforce unionization affect managerial pay. Personnel Psychology 54(4) 903.

Davis, S.J. 2008. The Decline of Job Loss and Why It Matters. American Economic Review: Papers and Proceedings 98:2 263-267.

Davis, S.J., R.J. Faberman, J. Haltiwanger, R. Jarmin, J. Miranda. 2008. Business Volatility, Job

Destruction and Unemployment. Unpublished Manuscript.

Dencker, J.C. 2009. Relative Bargaining Power, Corporate Restructuring, and Managerial Incentives.

Administrative Science Quarterly 54(3) 453-485.

DiPrete, T.A. 1993. Industrial Restructuring and the Mobility Response of American Workers in the 1980s. American Sociological Review 58(1) 74-96.

DiPrete, T.A., D. Goux, E. Maurin. 2002. Internal Labor Markets and Earnings Trajectories in the Post-

Fordist Economy: An Analysis of Recent Trends. Social Science Research 31(2) 175-196.

Doeringer, P.B., M.J. Piore. 1971. Internal labor markets and manpower analysis. Heath, Lexington,

Mass.,.

Dubofsky, M. 1994. The State and Labor in Modern America. University of North Carolina Press, Chapel

Hill.

Farber, H.S. 2008a. Employment Insecurity: The Decline in Worker-Firm Attachment in the United

States. Unpublished Manuscript.

Farber, H.S. 2008b. Job Loss and the Decline in Job Security in the United States. Unpublished

Manuscript.

Feenstra, R.C., J. Romalis, P.K. Schott. 2002. US Imports, Exports and Tariff Data. Unpublished

Manuscript.

Ferguson, J.-P. 2008. The eyes of the needles: A sequential model of union organizing drives, 1999-2004

Industrial \& Labor Relations Review. Cornell University, 3-21.

Fligstein, N., T. Shin. 2007. Shareholder Value and the Transformation of the U.S. Economy, 1984-2000.

Sociological Forum 22(4) 399-424.

Freeman, R.B. 1988. Contraction and Expansion: The Divergence of Private Sector and Public Sector

Unionism in the United States. The Journal of Economic Perspectives 2(2) 63-88.

Freeman, R.B., J.L. Medoff. 1981. The Impact of the Percentage Organized on Union and Nonunion

Wages. The Review of Economics and Statistics 63(4) 561-572.

Griffeth, R.W., P.W. Hom, S. Gaertner. 2000. A meta-analysis of antecedents and correlates of employee

turnover: update, moderator tests, and research implications for the next millenium. Journal of

Management 26(3) 463-488.

Hirsch, B.T. 2008. Sluggish institutions in a dynamic world: can unions and industrial competition

coexist? Journal of Economic Perspectives 22(1) 1133-1180.

Hirsch, B.T., M.C. Berger. 1984. Union Membership Determination and Industry Characteristics.

Southern Economic Journal 50(3) 665-679.

Hodson, R., R.L. Kaufman. 1982. Economic Dualism: A Critical Review. American Sociological Review 47(6) 727-739.

Hollister, M.N. 2004. Does Firm Size Matter Anymore? The New Economy and Firm Size Wage Effects. American Sociological Review 69(5) 659-676.

Hollister, M.N. 2011. Employment stability in the US labor market: Rhetoric vs Reality. Annual Review of Sociology 37(1) 305-324.

Hollister, M.N., K.E. Smith. 2011. Unmasking the conflicting trends in job tenure by gender in the United States, 1983-2010. Unpublished Manuscript. 
Hom, P.W., A.J. Kinicki. 2001. Toward a Greater Understanding of How Dissatisfaction Drives Employee Turnover. The Academy of Management Journal 44(5) 975-987.

Jacoby, S.M. 1985. Employing bureaucracy : managers, unions, and the transformation of work in American industry, 1900-1945. Columbia University Press, New York.

Jacoby, S.M. 1997. Modern manors: Welfare capitalism since the New Deal. Princeton University Press, Princeton, NJ.

Jovanovic, B. 1979. Job Matching and the Theory of Turnover. The Journal of Political Economy 87(5) 972-990.

Jung, J. 2011. Shareholder Value and Workforce Downsizing, 1984-2006. Unpublished Manuscript. Kambayashi, R., T. Kato. 2012. Trends in long-term employment and job security in Japan and the United States: the last twenty five years NBER Japan Project Meeting, Asian Development Bank Institute, Tokyo.

Kerr, C. 1977. The Balkanization of Labor Markets. C. Kerr, ed. Labor Markets and Wage Determination: the Balkanization of Labor Markets and Other Essays. University of California Press, Berkeley, CA, 21-37.

Kochan, T.A., H.C. Katz, R.B. McKersie. 1994. The transformation of American industrial relations, 1st ILR Press ed. ILR Press, Ithaca, N.Y.

Kronberg, A.-K. 2010. Stay or leave? How the exernal labor market strategy affected the racial earnings gap American Sociological Association Annual Meetings, Atlanta.

Levy, F., P. Temin. 2007. Inequality and institutions in 20th Century America. Unpublished Manuscript. MacDuffie, J.P. 1996. Automitive white collar: the changing status and roles of salaried employees in the North American auto industry. P. Osterman, ed. Broken ladders: managerial careers in the new economy. Oxford University Press, Oxford, 81-125.

Madrian, B.C., L.J. Lefgren. 1999. A Note on Longitudinally Matching Current Population Survey (CPS) Respondents. Unpublished Manuscript.

March, J.G., H.A. Simon. 1958. Organizations, 2nd ed. Blackwell, Cambridge, MA.

Murphy, R. 1988. Social closure: the theory of monopolization and exclusion. Clarendon Press, Oxford. Neumark, D., D. Polsky, D. Hansen. 1999. Has Job Stability Declined Yet? New Evidence for the 1990s. Journal of Labor Economics 17(4) S29-S64.

Osterman, P. 1999. Securing Prosperity. Princeton University Press, Princeton, NJ.

Osterman, P., T.A. Kochan, R.M. Locke, M.J. Piore. 2001. Working in America: a blueprint for the new labor market. MIT Press, Cambridge, MA.

Oyer, P., S. Schaefer. 2000. Layoffs and Litigation. The RAND Journal of Economics 31(2) 345-358. Petersen, T., I. Saporta. 2004. The Opportunity Structure for Discrimination. American Journal of Sociology 109(4) 852-901.

Pfeffer, J. 1983. Organizational Demography. Research in Organizational Behavior 5 299-357. Pfeffer, J., J.N. Baron. 1988. Taking the Workers Back out - Recent Trends in the Structuring of Employment. Research in Organizational Behavior 10 257-303.

Pfeffer, J., Y. Cohen. 1984. Determinants of Internal Labor-Markets in Organizations. Administrative Science Quarterly 29(4) 550-572.

Phillips, D.J. 2001. The Promotion Paradox: Organizational Mortality and Employee Promotion Chances in Silicon Valley Law Firms, 1946-1996. The American Journal of Sociology 106(4) 1058-1098.

Podgursky, M. 1986. Unions, Establishment Size, and Intra-Industry Threat Effects. Industrial and Labor Relations Review 39(2) 277-284.

Rosen, S. 1969. Trade Union Power, Threat Effects and the Extent of Organization. The Review of Economic Studies 36(2) 185-196.

Rousseau, D.M. 1995. Psychological contracts in organizations: Understanding written and unwritten agreements. Sage Publications, Thousand Oaks, CA.

Sennett, R. 1998. The Corrosion of character: The personal consequences of work in the new capitalism. W.W. Norton \& Company, New York.

Shin, T.J. 2007. The impact of structural dynamics on job mobility rates in the United States. Social 
Science Research 36(4) 1301-1327.

Skvoretz, J., D. Willer. 1993. Exclusion and Power: A Test of Four Theories of Power in Exchange

Networks. American Sociological Review 58(6) 801-818.

Slichter, S.H., J.J. Healy, R.E. Livernash. 1960. The impact of collective bargaining on management. The Brookings Institution, Washington D.C.

Sorensen, A.B. 2000. Toward a Sounder Basis for Class Analysis. American Journal of Sociology 105(6) 1523-1558.

Sorensen, A.B., A.L. Kalleberg. 1981. An outlineof a theory of the matching of persons to jobs. I. Berg, ed. Sociological Perspectives on Labor Markets. Academic Press, New York, 49-75.

Stinchcombe, A.L. 1965. Social Structure and Organizations. J.G. March, ed. Handbook of

Organizations. Rand McNally, Chicago, 142-193.

Tolbert, C., P.M. Horan, E.M. Beck. 1980. The Structure of Economic Segmentation: A Dual Economy Approach. The American Journal of Sociology 85(5) 1095-1116.

Tope, D., D. Jacobs. 2009. The Politics of Union Decline: The Contingent Determinants of Union Recognition Elections and Victories. American Sociological Review 74(5) 842-864.

Topel, R.H., M.P. Ward. 1992. Job Mobility and the Careers of Young Men. The Quarterly Journal of Economics 107(2) 439-479.

Tsui, A.S., J.L. Pearce, L.W. Porter, A.M. Tripoli. 1997. Alternative Approaches to the EmployeeOrganization Relationship: Does Investment in Employees Pay off? The Academy of Management Journal 40(5) 1089-1121.

Unicon. 2005. General Reference for All Current Population Series: Appendices and Discussions. Walton, R.E., R.B. McKersie. 1965. A behavioral theory of labor negotiations; an analysis of a social interaction system [by] Richard E. Walton [and] Robert B. McKersie. McGraw-Hill, New York,. Weber, M. 1968. Economy and Society: an outline of interpretive sociology. Bedminster Press, New York.

Weeden, Kim A. 2002. Why Do Some Occupations Pay More than Others? Social Closure and Earnings Inequality in the United States. American Journal of Sociology 108(1) 55-101.

Western, B., J. Rosenfeld. 2011. Unions, Norms, and the Rise in U.S. Wage Inequality. American Sociological Review 76(4) 513-537. 


\section{TABLE 1A: DESCRIPTIVE STATISTICS FOR MAIN VARIABLES}

\begin{tabular}{|c|c|c|c|c|c|c|c|c|c|c|c|c|c|c|c|}
\hline & & Mean & S.D. & & & & & & Corre & ations & & & & & \\
\hline & & & & 1 & 2 & 3 & 4 & 5 & 6 & 7 & 8 & 9 & 10 & 11 & 12 \\
\hline 1 & Year & 1998 & 6.97 & 1 & & & & & & & & & & & \\
\hline 2 & Tenure & 9.56 & 8.95 & -.04 & 1 & & & & & & & & & & \\
\hline 3 & Age & 43.72 & 8.97 & .06 & .4 & 1 & & & & & & & & & \\
\hline 4 & Age squared & 1992 & 817 & .05 & .4 & .99 & 1 & & & & & & & & \\
\hline 5 & High school & 0.89 & 0.31 & .09 & .02 & -.05 & -.06 & 1 & & & & & & & \\
\hline 6 & Associates & 0.40 & 0.49 & .04 & -.04 & -.02 & -.02 & .29 & 1 & & & & & & \\
\hline 7 & Bachelors & 0.31 & 0.46 & .05 & -.04 & 0 & 0 & .23 & .82 & 1 & & & & & \\
\hline 8 & Post grad & 0.11 & 0.31 & .03 & -.02 & .05 & .05 & .12 & .42 & .51 & 1 & & & & \\
\hline 9 & State unemp. & 5.85 & 1.85 & -.47 & .03 & -.02 & -.02 & -.06 & -.02 & -.02 & 0 & 1 & & & \\
\hline 10 & $1000+$ emp & 0.37 & 0.48 & -.05 & .15 & .01 & .01 & .09 & .08 & .07 & .03 & .03 & 1 & & \\
\hline 11 & Unionization & 0.14 & 0.14 & -.26 & .19 & .03 & .03 & -.05 & -.14 & -.16 & -.1 & .14 & .2 & 1 & \\
\hline 12 & Import pen. & 0.19 & 0.38 & .07 & .02 & .01 & .01 & .03 & .05 & .05 & .02 & -.02 & .06 & -.09 & \\
\hline 13 & Tech intens. & 0.01 & 0.02 & .07 & -.02 & -.01 & -.01 & .07 & .13 & .13 & .08 & -.04 & .07 & -.15 & \\
\hline
\end{tabular}

TABLE 1B: OVER TIME TRENDS IN MAIN INDEPENDENT VARIABLES

\begin{tabular}{lccc|ccc} 
& \multicolumn{3}{c|}{ Average by industry } & \multicolumn{3}{c}{ Average by worker } \\
\cline { 2 - 7 } year & Unionization & Import & penetration & Tech & \multicolumn{3}{c}{ Import } & Tech \\
1979 & 0.229 & 0.115 & 0.00275 & 0.274 & 0.136 & 0.00289 \\
1983 & 0.180 & 0.135 & 0.00360 & 0.217 & 0.117 & 0.00430 \\
1988 & 0.147 & 0.211 & 0.00476 & 0.173 & 0.145 & 0.00445 \\
1993 & 0.135 & 0.230 & 0.00607 & 0.165 & 0.153 & 0.00491 \\
1995 & 0.129 & 0.274 & 0.00607 & 0.145 & 0.186 & 0.00537 \\
1996 & 0.122 & 0.330 & 0.00602 & 0.140 & 0.192 & 0.00512 \\
1997 & 0.127 & 0.315 & 0.00753 & 0.144 & 0.209 & 0.00964 \\
1998 & 0.112 & 0.326 & 0.00753 & 0.132 & 0.173 & 0.00825 \\
1999 & 0.123 & 0.352 & 0.00753 & 0.135 & 0.186 & 0.00878 \\
2000 & 0.111 & 0.393 & 0.00753 & 0.129 & 0.205 & 0.00917 \\
2001 & 0.109 & 0.414 & 0.00753 & 0.126 & 0.204 & 0.00908 \\
2002 & 0.104 & 0.488 & 0.00817 & 0.120 & 0.213 & 0.00899 \\
2004 & 0.102 & 0.462 & 0.00812 & 0.108 & 0.196 & 0.00815 \\
2005 & 0.099 & 0.494 & 0.00812 & 0.105 & 0.229 & 0.00879 \\
2006 & 0.089 & 0.597 & 0.00813 & 0.102 & 0.238 & 0.00850 \\
2008 & 0.091 & & 0.00812 & 0.104 & & 0.00878
\end{tabular}

Note: Average by industry includes one observation per industry per year. Average by worker includes one observation per worker by year. 
TABLE 2: DETERMINANTS OF TENURE

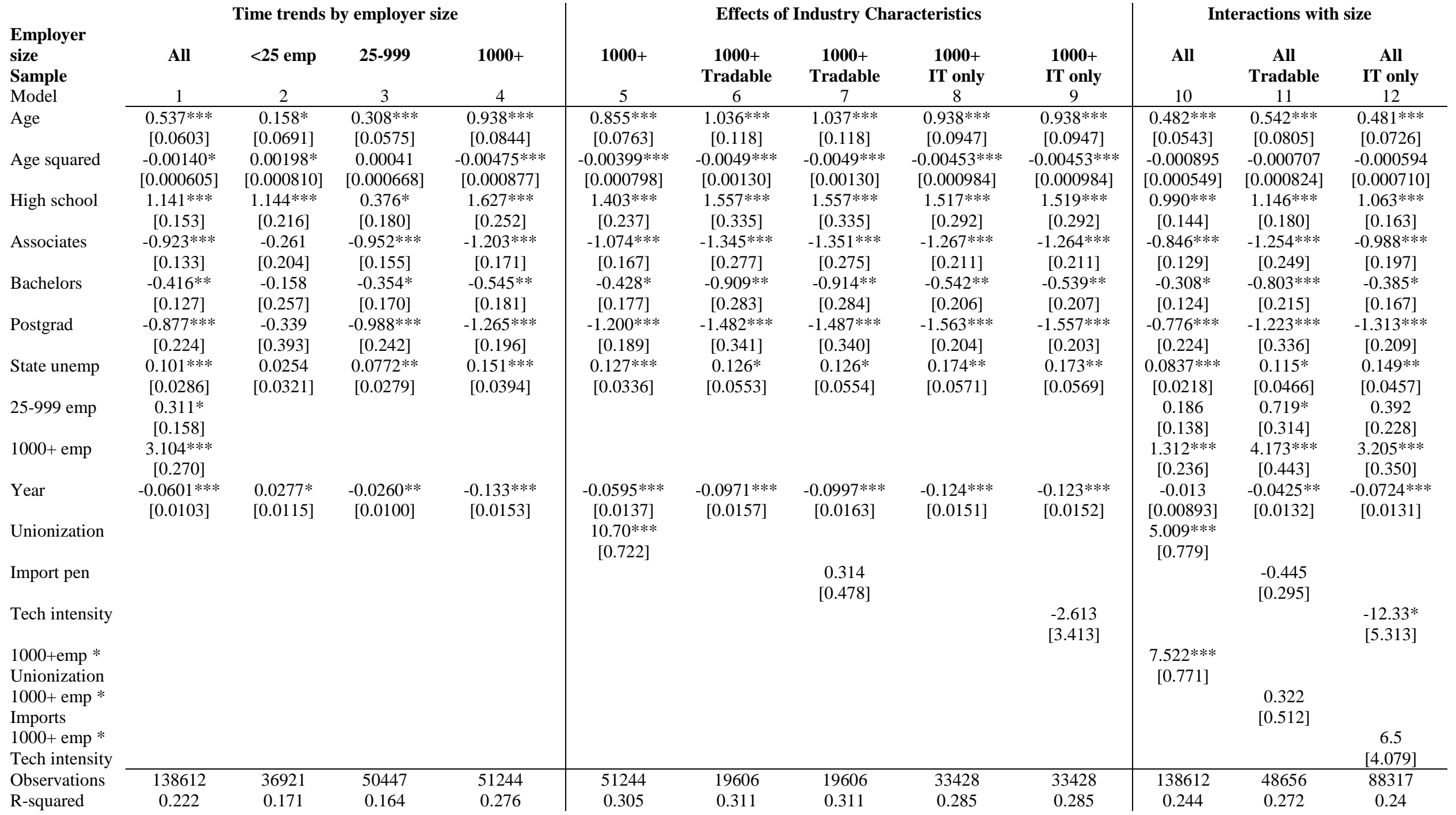

Note: OLS regression. Errors clustered by industry. All models control for 24 occupation dummies.

$* * * \mathrm{p}<.001 ; * * \mathrm{p}<0.01 ; * \mathrm{p}<0.05$ 


\section{TABLE 3: FURTHER ANALYSIS OF DETERMINANTS OF TENURE - LARGE EMPLOYERS ONLY}

\begin{tabular}{|c|c|c|c|c|c|c|c|c|c|}
\hline Sample & All & All & All & Union mem & Non union & Union mem & Non union & $\begin{array}{l}\text { Consistent } \\
\text { ind. }\end{array}$ & $\begin{array}{l}\text { Consistent } \\
\text { ind. }\end{array}$ \\
\hline Model & 1 & 2 & 3 & 4 & 5 & 6 & 7 & 8 & 9 \\
\hline \multirow[t]{2}{*}{ Age } & $0.877 * * *$ & $0.915 * * *$ & $0.818^{* * *}$ & $1.118^{* * *}$ & $0.866 * * *$ & $1.057 * * *$ & $0.825 * * *$ & $0.789 * * *$ & $0.788 * * *$ \\
\hline & {$[0.0774]$} & [0.0873] & {$[0.0785]$} & [0.164] & {$[0.0765]$} & {$[0.156]$} & {$[0.0741]$} & [0.0803] & [0.0797] \\
\hline \multirow[t]{2}{*}{ Age squared } & $-0.00416 * * *$ & $-0.00446 * * *$ & $-0.00354 * * *$ & $-0.00530 * *$ & $-0.00459 * * *$ & $-0.00473^{* *}$ & $-0.00420 * * *$ & $-0.00363 * * *$ & $-0.00362 * * *$ \\
\hline & [0.000812] & [0.000908] & [0.000821] & {$[0.00176]$} & [0.000836] & [0.00167] & [0.000809] & [0.000785] & [0.000778] \\
\hline \multirow[t]{2}{*}{ High school } & $1.238 * * *$ & $1.601^{* * *}$ & $1.182 * * *$ & $1.429 * * *$ & $1.754 * * *$ & $1.305 * * *$ & $1.532 * * *$ & $0.855 * * *$ & $0.879 * * *$ \\
\hline & {$[0.232]$} & [0.255] & [0.235] & [0.334] & [0.307] & [0.330] & [0.309] & [0.217] & [0.218] \\
\hline \multirow[t]{2}{*}{ Associates } & $-1.295^{* * *}$ & $-1.216^{* * *}$ & $-1.187^{* * *}$ & $-1.925^{* * *}$ & $-0.752^{* * *}$ & $-1.867 * * *$ & $-0.703^{* * *}$ & $-1.108^{* * *}$ & $-1.106^{* * *}$ \\
\hline & [0.167] & {$[0.176]$} & [0.169] & [0.334] & {$[0.177]$} & [0.319] & {$[0.174]$} & [0.173] & {$[0.172]$} \\
\hline \multirow[t]{2}{*}{ Bachelors } & $-0.678 * * *$ & $-0.517 * *$ & $-0.548 * *$ & $-1.050 * *$ & $-0.514^{*}$ & $-1.092 * *$ & $-0.449 *$ & $-0.400 * *$ & $-0.399 * *$ \\
\hline & {$[0.170]$} & [0.187] & [0.173] & {$[0.378]$} & {$[0.210]$} & [0.387] & {$[0.208]$} & {$[0.141]$} & {$[0.141]$} \\
\hline Post grad & $-1.264 * * *$ & $-1.186 * * *$ & $-1.124 * * *$ & -1.343 & $-1.269 * * *$ & -1.08 & $-1.243^{* * *}$ & $-1.204^{* * *}$ & $-1.203^{* * *}$ \\
\hline \multirow[t]{2}{*}{ State unemployment } & $0.128 * * *$ & $0.152 * * *$ & $0.118^{* * *}$ & 0.0881 & $0.131^{* *}$ & $0.0873+$ & $0.120 * *$ & $0.0798 * *$ & $0.0765 * *$ \\
\hline & {$[0.0365]$} & {$[0.0399]$} & {$[0.0332]$} & {$[0.0544]$} & {$[0.0413]$} & {$[0.0487]$} & {$[0.0377]$} & {$[0.0269]$} & {$[0.0269]$} \\
\hline \multirow[t]{2}{*}{ Year } & $-0.123 * * *$ & $-0.119 * * *$ & $-0.0610 * * *$ & $-0.0515^{*}$ & $-0.127 * * *$ & 0.0201 & $-0.0855 * * *$ & $-0.0789 * * *$ & $-0.0629 * * *$ \\
\hline & {$[0.0139]$} & {$[0.0157]$} & {$[0.0132]$} & {$[0.0247]$} & {$[0.0131]$} & {$[0.0239]$} & {$[0.0131]$} & {$[0.0134]$} & {$[0.0140]$} \\
\hline \multirow[t]{2}{*}{ Industry wage premium } & $8.322 * * *$ & & $5.783^{* * *}$ & & & & & & \\
\hline & {$[1.026]$} & & {$[0.820]$} & & & & & & \\
\hline Industry growth & & $-0.485^{* * *}$ & $-0.370^{* * *}$ & & & & & & \\
\hline since 1979 & & {$[0.111]$} & {$[0.0697]$} & & & & & & \\
\hline \multirow[t]{2}{*}{ Unionization } & & & $8.028 * * *$ & & & $8.379 * * *$ & $8.218 * * *$ & & $3.149+$ \\
\hline & & & {$[0.741]$} & & & {$[1.074]$} & {$[0.872]$} & & {$[1.797]$} \\
\hline Industry Fixed Effects & & & & & & & & Yes & Yes \\
\hline Observations & 51242 & 48410 & 48408 & 11476 & 37805 & 11476 & 37805 & 51017 & 51017 \\
\hline R-squared & 0.295 & 0.286 & 0.319 & 0.342 & 0.242 & 0.363 & 0.256 & 0.217 & 0.218 \\
\hline
\end{tabular}


TABLE 4: DETERMINANTS OF UNIONIZATION

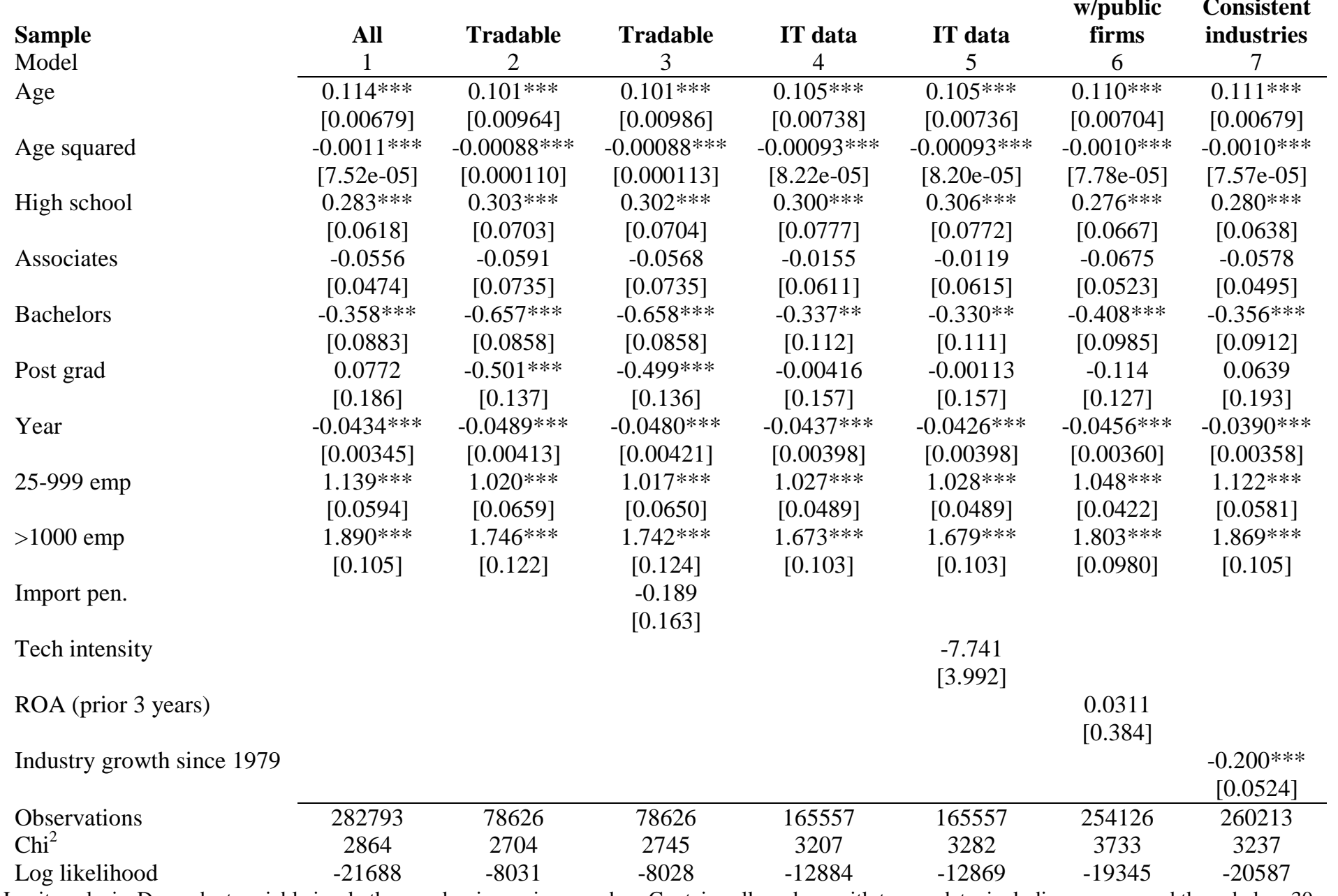

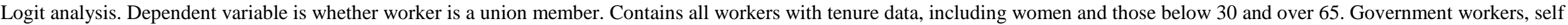

employed and usually part time dropped from analysis. All analyses control for occupation dummies. Errors clustered by industry $* * * \mathrm{p}<.001 ; * * \mathrm{p}<0.01 ; * \mathrm{p}<0.05$ 
TABLE 5: DETERMINANTS OF LAYOFFS

\begin{tabular}{|c|c|c|c|c|c|c|c|c|c|}
\hline Sample & All & All & All & Tradable & Tradable & Tradable & $\begin{array}{l}\text { w/ IT } \\
\text { data }\end{array}$ & $\begin{array}{l}\text { w/ IT } \\
\text { data }\end{array}$ & $\begin{array}{l}\text { w/ IT } \\
\text { data }\end{array}$ \\
\hline Model & 1 & 2 & 3 & 4 & 5 & 6 & 7 & 8 & 9 \\
\hline \multirow[t]{2}{*}{ Age } & 0.0121 & 0.0173 & 0.00348 & -0.012 & -0.0123 & -0.0201 & 0.00234 & 0.00231 & -0.00833 \\
\hline & [0.0117] & [0.0113] & [0.0108] & {$[0.0202]$} & [0.0203] & [0.0145] & [0.0180] & {$[0.0180]$} & [0.0143] \\
\hline \multirow[t]{2}{*}{ Age squared } & $-0.000259 *$ & $-0.000311^{*}$ & -0.00015 & -0.00001 & -0.00001 & 0.00012 & -0.00014 & -0.00014 & -0.00001 \\
\hline & [0.000129] & [0.000125] & [0.000120] & {$[0.000220]$} & [0.000221] & [0.000153] & [0.000197] & [0.000196] & [0.000156] \\
\hline \multirow[t]{2}{*}{ High school } & -0.0127 & 0.0041 & -0.00674 & -0.0563 & -0.0572 & -0.0392 & 0.0125 & 0.0109 & 0.0081 \\
\hline & [0.0285] & [0.0266] & [0.0322] & [0.0451] & [0.0443] & [0.0438] & [0.0449] & [0.0452] & [0.0582] \\
\hline Associates & [0.0324] & {$[0.0321]$} & [0.0365] & [0.0577] & [0.0578] & [0.0598] & [0.0437] & [0.0437] & [0.0572] \\
\hline \multirow[t]{2}{*}{ Bachelors } & $-0.0974^{*}$ & $-0.109 * *$ & $-0.0999 *$ & -0.0974 & -0.101 & -0.0982 & $-0.116^{*}$ & $-0.119 *$ & $-0.147^{*}$ \\
\hline & [0.0414] & [0.0413] & [0.0438] & {$[0.0728]$} & [0.0729] & [0.0672] & [0.0580] & [0.0579] & {$[0.0610]$} \\
\hline \multirow[t]{2}{*}{ Post grad } & $-0.210 * *$ & $-0.226^{* * *}$ & $-0.214^{* *}$ & -0.015 & -0.0155 & -0.124 & -0.0699 & -0.0758 & -0.0506 \\
\hline & {$[0.0656]$} & [0.0673] & {$[0.0667]$} & [0.0820] & [0.0812] & [0.0917] & [0.0574] & [0.0574] & [0.0602] \\
\hline \multirow[t]{2}{*}{ Year } & -0.00195 & -0.00674 & $-0.0082 * *$ & -0.00494 & -0.00537 & $-0.00927 *$ & -0.00138 & -0.00214 & $-0.0142 * *$ \\
\hline & [0.00376] & {$[0.00348]$} & [0.00291] & [0.00601] & [0.00504] & {$[0.00372]$} & [0.00421] & [0.00415] & [0.00439] \\
\hline $\begin{array}{l}\text { Unionization } \\
\text { (current ind) }\end{array}$ & & $\begin{array}{c}-1.050^{* * *} \\
{[0.183]}\end{array}$ & & & & & & & \\
\hline Unionization & & & $-0.485 *$ & & & & & & \\
\hline (initial ind) & & & {$[0.224]$} & & & & & & \\
\hline $\begin{array}{l}\text { Import pen } \\
\text { (current ind) }\end{array}$ & & & & & $\begin{array}{l}0.220 * * * \\
{[0.0599]}\end{array}$ & & & & \\
\hline Import pen & & & & & & $0.252 * * *$ & & & \\
\hline (initial ind) & & & & & & [0.0705] & & & \\
\hline Tech intensity & & & & & & & & $2.974 * * *$ & \\
\hline (current ind) & & & & & & & & [0.671] & \\
\hline $\begin{array}{l}\text { Tech intensity } \\
\text { (initial ind) }\end{array}$ & & & & & & & & & $\begin{array}{c}4.487 * * * \\
{[0.712]}\end{array}$ \\
\hline Observations & 230353 & 230353 & 225728 & 79473 & 79473 & 79292 & 129340 & 129340 & 126925 \\
\hline chi2 & 531.4 & 718.5 & 638 & 938.6 & 981.2 & 1033 & 455.7 & 509.1 & 545 \\
\hline Log likelihood & -25744 & -25691 & -24950 & -9445 & -9437 & -9955 & -14831 & -14825 & -14684 \\
\hline
\end{tabular}

Logit analysis. Dependent variable is whether worker has been laid off within the last three years. "Current ind” refers to characteristics of industry laid off workers are employed by at time of survey. "Initial ind" refers to characteristics of industry laid off workers were employed by before layoffs. Industry remains same for all workers who were not laid off. All analyses control for occupation dummies. Errors clustered at industry level.

$* * * \mathrm{p}<.001 ; * * \mathrm{p}<0.01 ; * \mathrm{p}<0.05$ 


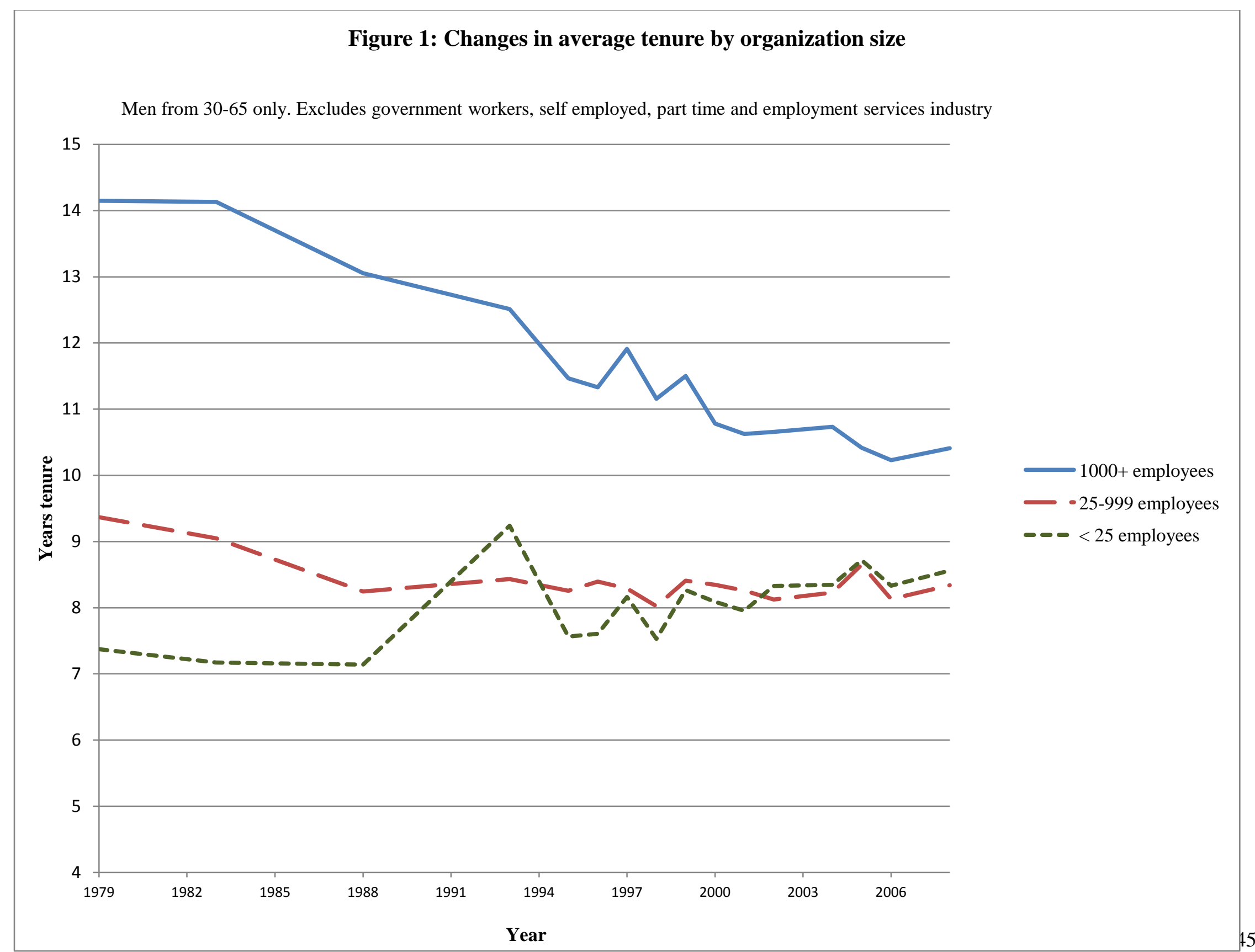

